\title{
Uluslararası İlişkiler Disiplininde Ontolojik Güvenlik Teorisi: Kavram ve Literatür Odaklı Bir İnceleme
}

39

Güvenlik Stratejileri

Cilt: 17

Say1: 37

\section{$\ddot{O} z$}

Bu makale, Türkiye'de yeterince iyi taninmayan, ancak Battl Uluslararası İlişkiler (UI) yazınında uzunca bir süredir çalışılan "Ontolojik Güvenlik Teorisini" (OGT), çeşitli kavramsal ve pratik tartışmalarla, tanımlayıcı yaklaşımla incelemektedir. Giddens' in "insanın öz-kimliğinin sürekliliğine ve çevresindeki sosyal ve maddi eylem ortamlarının tutarlılığına duyduğu güven" olarak açıkladığı ontolojik güvenlik; insanlar kadar, toplumların ve devletlerin de yaşamlarındaki rutinler, sosyal etkileşimler ve istikrarla bağlantılıdır. Bu noktada çok sayıda iç ve dış politika eyleminin arka planında ontolojik güvenlik ya da güvensizlik olgusunun yattı̆̆ görülmekte; tekrarlayan çatışmalar ve irrasyonel devlet davranısları bu kavram üzerinden sosyo-psikolojik bir altyap ile incelenebilmektedir. Bu araştırma hem kavrama dair tanımlart derinlemesine ele almakta, hem de konuyla ilgili çeşitli vaka analizlerini geniş bir literatür taramasıyla ortaya koymaktadır. Amaç, Türkiye'de

\footnotetext{
Doç Dr., İstanbul Medeniyet Üniversitesi, Uluslararası İlişkiler Bölümü, ORCID:0000-0003-0008-9781, e-posta: helin.sariertem@medeniyet.edu.tr.

** Doktora Aday1, İstanbul Medeniyet Üniversitesi, Lisansüstü Eğitim Enstitüsü, ORCID:0000-0001-7473-7169, e-posta: aslinurd@ gmail.com.
}

Geliș Tarihi / Submitted: 04.04.2020

Kabul Tarihi / Accepted: 04.03.2021 
40

Güvenlik Stratejileri

Cilt: 17

Sayı: 37

Uİ alanında gelecekte yapılacak güvenlik ve dış politika çalışmalarının, bu tartışmalar eşliğinde analitik bir zenginlik kazanmasına katk sağlamaktır. Öz-kimlik/benlik ve güvenlik ilişkisine dair bulguları ve disiplinlerarası yapısı sayesinde, ontolojik güvenlik yaklaşımı böyle bir potansiyele fazlasiyla sahiptir.

Anahtar Kelimeler: Ontolojik Güvenlik Teorisi, Ontolojik Güvensizlik, Öz-kimlik, Rutinler, Kaygl.

\section{Abstract}

Together with various conceptual and practical discussions, this article descriptively examines the 'Ontological Security Theory' (OST), which is not well known enough in Turkey, but has long been studied in the Western International Relations (IR) literature. Ontological security, which is defined by Giddens as the "confidence human beings have in the continuity of their self-identity and in the constancy of the surrounding social and material environments of action", is linked to the routines, social interactions and stability in the lives of the societies and the states, similar to the individuals. At this point, it is seen that behind many domestic and foreign policy actions, there lies the phenomenon of ontological security or insecurity; and a significant amount of the discussions on the protracted conflicts and the irrational state behaviors can be analysed by means of socio-psychological base via this concept. This research both addresses the definitions of the concept in a deeply manner and presents various case studies related to the issue through a wide literature review. The aim is to contribute to the analytical enrichment of the future IR studies in Turkey on security and foreign policy, through these discussions. Thanks to its interdisciplinary structure and findings on the relationship between self-identity/the self and security, the ontological security approach exceedingly holds such a potential.

Keywords: Ontological Security Theory, Ontological Insecurity, Self-identity, Routines, Anxiety. 
Uluslararası İlişkiler Disiplininde Ontolojik Güvenlik Teorisi:

Kavram ve Literatür Odaklı Bir İnceleme

\section{Giriş}

Abraham Maslow'un Ihtiyaçlar Hiyerarşisi'ne göre; insanın yeme, içme, uyuma ve barınma gibi mutlaka giderilmesi gereken yaşamsal/fizyolojik ihtiyaçlarından hemen sonra gelen ikinci en önemli ihtiyacı güvenlik ve korunmadır. ${ }^{1}$ Güvenlik ya da güvende olma, en basit tanımıyla bireyin bedeninin dış tehditlerden muaf ve emniyette olması anlamına gelse de aslında çok daha geniş bir içerik taşımakta; sağlığın, işin, ailenin, sahip olunan kaynakların, mülkün, ahlak ve değerlerin; hatta içinde yaşanılan toplumun güvende olmasını ifade etmektedir. Fizyolojisi ve güvenliğine dair ihtiyaçları belirli bir oranda karşılanmayan insanın, Maslow piramidindeki sırasıyla, diğer üç ana ihtiyacı temsil eden sevgi (aidiyet), saygı ve kendini gerçekleştirme ihtiyaçlarını karşılaması da mümkün olmayacaktır. ${ }^{2}$

Muğlak niteliğine dikkat çektiği güvenliği; nesnel ve öznel anlamlarına ayırarak ele alan Wolfers, kavramı, "objektif anlamda, sahip olunan değerlere yönelik bir tehdidin; sübjektif anlamda ise, bu değerlerin saldırıya uğrayacağına dair bir korkunun olmaması" durumu olarak tanımlamaktadır. ${ }^{3}$ Buzan da benzer bir şekilde, güvenlik tartışmalarının "tehditten muaf olma arayışı" ile ilgili olduğunu belirtmektedir. ${ }^{4}$ Güvenlik; dış dünyanın beyne yansıma şekilleri olarak tanımlanabilecek algılarla yakın bir ilişki içindedir ve bu algılar sübjektif yargılar içerir. ${ }^{5}$ $\mathrm{Bu}$ açıdan güvenlik, tıpkı dost, düşman, tehdit ve çıkar tanımlarında olduğu gibi yoruma açık yapıdadır ve öznel çıkarımlarla tanımlanır.

\footnotetext{
${ }^{1}$ Abraham H. Maslow, “A Theory of Human Motivation", Psychological Review, 1943, Cilt: 50, No: 4, 370-396, ss. 376-380.

${ }^{2}$ A.g.m.; ayrıca bkz. Sedat Kula ve Bekir Çakar, "Maslow İhtiyaçlar Hiyerarşisi Bağlamında Toplumda Bireylerin Güvenlik Algısı ve Yaşam Doyumu Arasındaki İlişki”, Bartın Üniversitesi IIIBF Dergisi, 2015, Cilt: 6, No: 12, 191-210, s. 193.

3 Arnold Wolfers, "National Security as an Ambiguous Symbol", Political Science Quarterly, 1952, Cilt: 67, No: 4, 481-502, s. 485.

${ }^{4}$ Barry Buzan, People, States and Fear: An Agenda for International Security Studies in the Post-Cold War Era, (2nd Edition), ECPR Press, Colchester, 2007, s. 37.

${ }^{5}$ James Chace ve Caleb Carr, America Invulnerable: The Quest for Absolute Security from 1812 to Starwars, Summit Books, New York, 1988, s. 74.
}

\section{1}

Güvenlik Stratejileri

Cilt: 17

Say1: 37 
Güvenlik Stratejileri

Cilt: 17

Sayı: 37

$\mathrm{Bu}$ makalenin konusunu oluşturan ontolojik güvenlik kavramı ise Maslow piramidindeki hiyerarşiyi sorgulayan bir bakış açısı sunarak bireyin "iç-kaynaklı varlığına" ve bu varlığın öz-kimliğinin ${ }^{6}$ (self-identity) istikrarını sağlayan anlatı ve rutinlere odaklanırken; aktörlerin -kimi zaman- fiziksel güvenliğe ve onun öncüllüğüne meydan okuyan güvenlik algılarını çözümlemeye yönelik sosyo-psikolojik bir perspektif sunmaktadır. "Bir aktöre (birey/devlet) aktörlüğünü veren içsel dinamiklerin, farklı zaman ve koşullarda bilişsel veya pratik düzeyde istikrarının sağlanması hali" veya başka bir deyişle "kimlik/benlik/varolma-olarak-güvenlik"7 ile uyumlu şekilde tercih edilen biyografik anlatılar ve rutinlerle, dışsal etkileşimde ontolojik kaygıların paranteze alınması, tutarlı bir benlik/kimlik anlayışının sürekli/kesintisiz olmasını sağlayabilmek" olarak tanımlayabileceğimiz "ontolojik güvenlik" (ontological security) de algilarla ilgilidir ve sübjektiftir.

Ontolojik ya da varoluşsal güvenlik kavramını, onu ilk kez psikoloji alanında kullanan R.D. Laing'den ödünç alarak sosyoloji literatürüne kazandıran kişi A. Giddens'tır. Giddens, bireylerin sosyal

6 “Giddens “öz-kimlik” kavramını, bireylerin sahip oldukları özelliklerin toplamı olarak değil, bireyin, benliğini kendi biyografisi ile bağlantılı olarak öz-dönüşümsel olarak anlaması" olarak tanımlamaktadır. Akt. Filip Ejdus, Crisis and Ontological Insecurity: Serbia's Anxiety over Kosovo's Secession, Palgrave Macmillan, Switzerland, 2020, s. 9. Detaylar için bkz. Anthony Giddens, The Constitution of Society: Outline of the Theory of Structuration, University of California Press, Berkeley, 1984.

${ }^{7}$ Ontolojik Güvenlik Teorisi (OGT) literatüründe ontolojik güvenliğin kaynağı genel olarak "kimlik" (security of identity) veya "benlik" (security of the self) olarak tanımlanmıştır. Bahar Rumelili, benlik-kimlik farklılığına ve anlamda netlik gerekliliğine dikkat çekerek, "iç-kaynaklı varlı" ve/veya "var olma-olarak-güvenlik" (security-as-being/security of being) nitelemesinde bulunmaktadır. Ontolojik güvenlik kaynağına dair OGT literatüründe var olan bu farklılıklar/çeşitlilik aynı zamanda bir tartışma konusudur. Bu çalışmada, bahsi geçen kavramları bir arada kullanma güçlügü nedeniyle (genellikle) kısaca "var-olmaolarak güvenlik" kavramı tercih edilmiştir ancak çalışma OGT literatür taramasını da kapsadığı için, akademisyenlerin çalışmalarıyla bağlantılı olarak "benlik" ve "kimlik" kavramları da yer almaktadır. Detaylar için bkz. Bahar Rumelili ve Umut Can Adısönmez, "Uluslararası İlişkilerde Kimlik Güvenlik İlişkisine Dair Yeni bir Paradigma: Ontolojik Güvenlik Teorisi”, Uluslararası İlişkiler, 2020, 1-17, s. 4. 
Uluslararası İlişkiler Disiplininde Ontolojik Güvenlik Teorisi:

Kavram ve Literatür Odaklı Bir İnceleme

hayat içinde deneyimledikleri rutinlerin, onların güvenlik algısını şekillendiren ana unsur olduğunu öne sürer. Buna göre, "tekrarlanan davranış kalıpları" olarak tanımlayabileceğimiz rutinlerden oluşan sosyal yapının devamı, kişinin kendisini tam anlamıyla güvende hissetmesinin asli unsurudur. ${ }^{8}$ Giddens, öz-kimliklerinin güvende olduğu hissine ihtiyaç duyan bireylerin, ontolojik güvenliklerini sağlayabilmek için birtakım rutin davranış kalıplarına bağlandıklarını savunmaktadır. Buna göre bireyler, güvende olma ihtiyacının yarattığı bir dürtüyle, tehdit olarak algılanan bilişsel ve duygusal belirsizliklerden kaçarak, istikrarı sağlayacak bu rutinlere bağlanırlar. Mitzen'e göre söz konusu rutinler, bireysel düzeydeki sosyal etkileşimle yakından ilişkilidir. "Öteki”lerle "ben"in ilişkisinde öngörülebilen davranış kalıpları, ontolojik güvenlik hissi verir ve bu nedenle bilinen, istikrarlı ilişkiler devam ettirilir. ${ }^{9}$

Uluslararası İlişkiler (UI) disiplininde ontolojik güvenlik çalışan öncüllerden olan Jennifer Mitzen, birey bazında ontolojik güvenliği, temel bir ihtiyaç olarak bedenin değil "benliğin" güvenliği olarak tanımlamaktadır. ${ }^{10}$ Bedenin güvenliğinin sağlandığı, diğer bir deyişle fiziksel güvenliğin olduğu durumlarda, eğer benliğin güvenliği sağlanamamışsa, ontolojik güvenlikten söz edilemez. ${ }^{11}$ Birey kendisini güvende hissetmek için netlik ister; olabilecekleri tahmin edebilmek ve geleceği planlayabilmek için sürekli bir çaba içindedir. Bu nedenle de Giddens'ın ontolojik güvenlik tanımı; bireyin "kendi olmak" ve

\footnotetext{
${ }^{8}$ Akt. Bahar Rumelili, "Ontological (In)security and Peace Anxieties: A Framework for Conflict Resolution", Bahar Rumelili (ed.), Conflict Resolution and Ontological Security, Routledge, New York, 2015, 10-29, s. 10. Detaylar için bkz. Anthony Giddens, Central Problems in Social Theory: Action, Structure and Contradiction in Social Analysis, Palgrave Macmillan, England, 1979, s. 219.

9 Jennifer Mitzen, "Ontological Security in World Politics: State Identity and the Security Dilemma", European Journal of International Relations, 2006, Cilt: 12, No: 3, 341-370, s. 342. ${ }^{10}$ A.g.m.; ss. $344-345$.

${ }^{11}$ Bahar Rumelili'ye göre, ontolojik güvenlik, varoluş anlamında güvenlik (security-asbeing); fiziksel güvenlik ise, beka anlamında güvenliktir (security-as-survival). Bkz. Bahar Rumelili, "Identity and Desecuritization: The Pitfalls of Conflating Ontological and Physical Security", Journal of International Relations and Development, 2013, 1-23, s. 2.
}

43

Güvenlik Stratejileri

Cilt: 17

Say1: 37 
44

Güvenlik Stratejileri

Cilt: 17

Sayı: 37

beklentilerini gerçekleştirebilmek için duyduğu istikrar ihtiyacını da içermektedir. ${ }^{12} \mathrm{Bu}$ açıdan ontolojik güvenlik, Maslow piramidini sarsan şekilde, hiyerarşinin en üst sırasında yer alan "kendini gerçekleştirme ihtiyacı" ile bağlantılıdır. Bireyin, gündelik hayatında kontrol edemeyeceğini bildiği fiziki ve sosyal tehlikelerin var olma ihtimali, belirsizliğe ve bu belirsizlikten doğan bir kaygıya neden olacaktır. Bu yüzden de bireyler, travmatik bazı istisnalar haricinde, kimliklerinin/benliklerinin istikrarını sağlayan ve güvende hissettiren sosyal ilişkilere ihtiyaç duyacaktır.

Antropomorfik bir bakış açısıyla birey düzeyinden devlet düzeyine geçiş yaparak, kavramı Uİ disiplinine uygulayan akademisyenler, devletlerin de tıpkı insanlar gibi ontolojik güvenlik arayışında olduklarını öne sürmekte; bu arayışı da fiziksel güvenlik söylemlerini yadsımadan; kimliğii/benliği/iç-kaynaklı varlığ 1 güvenli hale getiren biyografik-anlatılar ve rutinleşmiş davranışlar gibi öğelerle açıklamaya çalışmaktadırlar. Buna göre, ontolojik güvenlik arayışındaki devletler de, tıpkı bireyler gibi, hem iç dünyasında hem de "ötekilerle" etkileşimlerinde istikrar peşindedir ve diğer devletlerle rutin ilişkiler geliştirerek dış dünyayı göreceli olarak güvenli ve istikrarlı hale getirme amacındadır. ${ }^{13}$ Birey düzeyinden toplum ve devlet düzeylerine geçiş yapılarak uygulanan teori, sosyo-psikolojik altyapısı ve fiziksel güvenlik arayışıyla açıklanamayan irrasyonel devlet davranışlarını açıklamada başarılı bir teorik araçtır. Ontolojik güvenlik kavramını, varoluşçu teorisyenlerden esinlenerek 1960'ta Psikoloji alanına taşıyan Laing ve 1980'lerin sonlarında Sosyoloji alanına taşıyan Giddens'tan sonra 1998'de Huysmans Uİ disiplinine aktarmıştır. ${ }^{14}$ Huysmans'1 takip

${ }^{12}$ Helin Sarı Ertem, Geleneksel Amerikan Kimlik ve Güvenlik Algısının 11 Eylül Sonrası ABD Dış Politikasına Etkileri, Yayınlanmamış Doktora Tezi, Marmara Üniversitesi Sosyal Bilimler Enstitüsü, İstanbul, 2010, ss.71-72.

${ }^{13}$ Mitzen, "Ontological Security in World Politics...", s. 348.

${ }^{14}$ Aslında Uİ disiplininde ontolojik güvenlik kavramını ilk kez tanımlayan kişi Alexander Wendt'tir. "İstikrarlı bir sosyal kimlik arzusu yaratan dünyayla ilișkilerde öngörülebilirlik" olarak tanımladığı ontolojik güvenliği: "fiziksel güvenlik", "diğer aktörler tarafindan tanınma" ve "gelişme gereklilikleri" ile birlikte uluslararası alanda devletlerin sahip 
Uluslararası İlişkiler Disiplininde Ontolojik Güvenlik Teorisi:

Kavram ve Literatür Odaklı Bir İnceleme

eden McSweeney ve Manners da Uİ alanında kavramın anlamsal derinliğini kullanarak çalışmalar yapmışlardır. Kavramın farklı bir Uİ teorisi olarak geliştirilmesini ve gündeminin belirlenmesini sağlayan akademisyenler ise 2000'lerin başlarında ontolojik güvenlik çalışmalarıyla ünlenen Mitzen, Kinnvall ve Steele'dir.

$\mathrm{Bu}$ çalışma Türkiye'de görece az tanınan Ontolojik Güvenlik Teorisi (OGT) çalışmalarının, Uİ'de kimlik ve güvenlik odaklı akademik araştırmalara daha fazla katkı yapması amacıyla hazırlanmıştır. İnsan, toplum ve devlet yaşamındaki rutinler, kaygı, sosyal etkileşimler ve istikrarla doğrudan bağlantılı olan ontolojik güvenlik yaklaşımını, ortaya çıkışı ve öncül isimler tarafından farklı vakalarda uygulanma biçimleri açısından, tanımlayıcı bazda ele alan makale, konuyla ilgili çeşitli örnek çalışmaları geniş bir literatür taramasıyla ortaya koymaktadır. Makale temelde, "Ontolojik güvenlik ne demektir?"; "Rutinler, ontolojik güvenliği anlamlandırmada nasıl bir rol oynar?"; "Ontolojik güvensizliğe sebep olan kayg1 nasıl tanımlanır?"; "Uİ literatüründe ontolojik güvenlik çalışmaları yapan öncül isimlerin çalışmaları hangi minvaldedir?" ve "OGT nasıl bir gelişim göstermiştir?" gibi sorulara cevap aramaktadır.

$\mathrm{Bu}$ hedefle, makale öncelikle kavramın tanımı ve belirleyici unsurları üzerinde duracak; ardından uluslararası ve ulusal literatürde ontolojik güvenlik alanında öne çıkan başlıca çalışmalara değinecektir. Makale son olarak, yeterince tanındığında bu kavramın, Türkiye'deki UI çalışmalarına, bazı sorun alanlarının analizinde nasıl bir katkı sunabileceğine dair önerilerde bulunacaktır. Bu kapsamda ilk bölümde, ontolojik güvenlik, rutinler, ontolojik güvensizlik ve kaygı tanımlarına yer verilecek ve bu yol aracılığıyla okuyucuya ontolojik güvenlik yaklaşımının ana hatları yansıtılacaktır. İkinci bölümde ise ontolojik

oldukları dört önemli amaçtan biri olarak kabul etmiştir. Ontolojik güvenliği tanımlıyor olmasına rağmen Wendt'in OGT odaklı bir çalışması bulunmamaktadır. Alexander Wendt, "Collective Identity Formation and the International State", American Political Science Review, Cilt: 88, No: 2, 385. 
46

Güvenlik

Stratejileri

Cilt: 17

Sayı: 37

güvenliğin Uİ disiplini içindeki yeri; ne tür vakalarda analiz aracı olarak kullanıldığı, Mitzen, Kinnvall ve Steele'nin eserleri üzerinden incelenecektir. ${ }^{15}$ Çalışma, örnekleri henüz az da olsa, konu ile ilgili Türkiye'de yapılmış araştırmalara da yine bu bölüm içinde yer vermektedir. Araştırma, Kinnvall, Mitzen ve Steele'nin anahtar kelimelerinde doğrudan "ontolojik güvenlik" ya da "ontolojik güvensizlik" kavramları geçen çalışmalarıyla sınırlandırılmış olup, bu kavramı dolaylı olarak barındıran diğer eserler ve OGT konulu makaleler kapsam dışı bırakılmıştır.

\section{Bir Kavram Olarak "Ontolojik Güvenlik"}

Ontolojik güvenlik kavramını varoluşçu teorisyenlerden psikanalitiğe aktaran Laing, kavramı, bireyin öz-kimliğini ve özerkliğini şüpheden uzak ve sürekli olarak hissetme hali olarak tanımlamaktadır. ${ }^{16}$ Laing'e göre, ontolojik güvenliğe sahip birey; "gerçek, canlı, bütün, içsel anlamda tutarlı ve süreklilik arz eden bir varlıktır." ${ }^{17}$ Kavrama bugünkü ününü kazandıran asıl isim olan Giddens ise The Consequences of Modernity çalışmasında ontolojik güvenliği, "insanın kendi kimliğinin sürekliliğine ve çevresindeki sosyal ve maddi eylem ortamlarının tutarlılığına duyduğu güven" ${ }^{\prime 18}$ olarak ifade etmekte; hem insanlara

${ }^{15}$ Uİ disiplininde 2000'lerin başlarında ünlenmeye başlayan Ontolojik Güvenlik Teorisi (OGT) hali hazırda inşa edilmeye devam etmektedir. Yaklaşık 20 sene içinde farklı analiz düzeylerinde (birey, grup, toplum, devlet), farklı metodlarla (niteliksel, niceliksel, söylem analizleri), kavram-içi farklı kabullerle (kimlik/benlik/var-olma-olarak güvenlik veya kaygı kavramı tanım farklılıkları vb.), diğer teorilerin perspektifleriyle birlikte (postkolonyalizm, güvenlikleştirme vb.) çalışılarak farklı sonuçlar elde edilen çalışmalarla zenginleşmiştir. OGT literatüründeki bu çeşitlilik kimi zaman da bir belirsizlik kaynağı olarak eleştirildiği gibi, OGT çalışan akademisyenler tarafindan da tartışılmaktadır. Detaylar için bkz. Catarina Kinnvall ve Jennifer Mitzen, "An Introduction to the Special Issue: Ontological Securities in World Politics", Cooperation and Conflict, 2017, Cilt: 52, No: 1, 3-11; Rumelili ve Adısönmez, "Uluslararası İlişkilerde Kimlik Güvenlik...; Ejdus, Crisis and Ontological....

${ }^{16}$ Ronald David Laing, The Divided Self: An Existential Study in Sanity and Madness, Penguin Classics, London, 1990, (ilk basim y1l1 1959), s. 41.

${ }^{17}$ A.g.e., s. 39; s. 41. Laing, "ontolojik" sözcüğünü, "varoluşu” (being) en iyi anlatan zarf ya da sıfat olduğu iddiasıyla seçmiştir.

${ }^{18}$ Anthony Giddens, The Consequences of Modernity, Polity Press, United Kingdom, 
Uluslararası İlişkiler Disiplininde Ontolojik Güvenlik Teorisi:

Kavram ve Literatür Odaklı Bir İnceleme

hem de fiziki çevreye duyulan güveni, ontolojik güvenliğe dair duygular için temel olarak almaktadır. ${ }^{19}$ Belirsizlikler ve süreksizliklerle dolu dünya hayatının doğurduğu kaygının ontolojik güvensizlik problemine yol açacağını düşünen Giddens'a göre, insan varlığının önemli bir unsuru olan ontolojik güvenlik kavramı, sosyal ve fiziksel hayatın sürekliliğiyle oluşan güvenden doğmaktadır. Özetle, Giddens için ontolojik güvenlik, derin belirsizliklerle dolu hayat akışında bireyin varoluşsal kaygılardan kaçarak ürettiği biyografik-anlatılarının sürekliliğini ifade etmektedir. ${ }^{20}$

Kinvall kavramı, "varoluşumuzun güvenliği; etrafımızı saran dünyanın göründüğü gibi olduğuna duyulan inanç ve güven" olarak tanımlarken" ${ }^{21}$ Innes ve Steele ise "zaman ve mekânda tutarlı bir özbenlik arayışı ve bu benliğin başkaları tarafindan tanınması ve onaylanmas1 arzusu" 22 olarak betimlemektedir. Buna göre, ontolojik güvenlik durumundaki birey, kendisinin kim olduğuna dair öznel algısını biyografik anlatılarla yansıtmakta; bu sayede de seçim yaparak eylemde bulunma imkânı bulmaktadır. ${ }^{23}$ Bireyin dünya üzerindeki emniyet duygusunu ifade eden ve ona, sosyal ve fiziksel etkileşimlerinde gerçekleşmesi mümkün riskleri adeta unutturan bu olgu sayesinde birey $^{24}$ hayata dair duyduğu endişelerden kurtulmaya çalışmakta; düzen ve istikrar arzusuyla, adeta kendisine yönelik hiçbir tehlike

1990, s. 92.

${ }^{19}$ A.g.e., s. 92.

${ }^{20}$ Akt. Catarina Kinnvall, "Globalization and Religious Nationalism: Self, Identity, and the Search for Ontological Security”, Political Psychology, 2004, Cilt: 25, No: 5, 741-767, s. 746, Detaylar için bkz. Giddens, The Consequences of Modernity.

${ }^{21}$ Kinnvall, "Globalization and Religious Nationalism: Self, Identity...", s. 746.

${ }^{22}$ Brent J. Steele ve Alexandria J. Innes, "Memory, Trauma and Ontological Security", Erica Resende ve Dovile Budryte, (ed.), Memory and Trauma in International Relations: Theories, Cases and Debates, Routledge, New York, 2014, 15-29, s. 15.

${ }^{23}$ Mitzen, "Ontological Security in World Politics...", s. 344.

${ }^{24}$ Anthony Giddens, Modernity and Self-Identity: Self and Society in the Late Modern Age, Polity Press, Cambridge, 2006, s. 40. 


\section{8}

Güvenlik Stratejileri

Cilt: 17

Sayı: 37

yokmuşçasına, öz-kimliğinin sürekliliğini sağlayarak yaşamaya çalışmaktadır. ${ }^{25}$

UI disiplininde gerçekleştirilen ontolojik güvenlik çalışmaları Giddens formülasyonuna dayanarak; birey düzeyinden devlet düzeyine geçmekte, devleti adeta insansılaştırarak, fiziksel güvenlik çalışmaları ile anlaşılamayan devletlerarası rutinleri, devlet kimliklerini ve davranışlarını sorgulamaktadır. $\mathrm{Bu}$ noktada ontolojik güvenlik kavramının ana unsurlarından biri olan "rutinlere" daha yakından bakmakta fayda vardır.

\section{Ontolojik Güvenliğin "Rutinler”le İlișkisi}

Giddens, günlük yaşamda önceden bilinen "rutinleri”, ontolojik güvenliğin sağlayıcıları olarak görmektedir. Ona göre bireyler, kendilerini ontolojik anlamda güvende hissedebilmek için öz-kimliklerini, özanlatılarını devam ettirecek birtakım rutinler yerleştirir. Bu rutinler çocukluk evresinden başlamakta ve güven duygusuna kaynaklık etmektedir. Toplumsal yaşam içindeki rutinlerle öngörülebilen davranışlar sayesinde bireyler, yaptıkları eylemlerde ontolojik güvenlik duygusuyla hareket eder; alışkanlıkların ve rutinlerin sürdürülmesiyle, ihtimal dâhilindeki tehditlerin kaygısından korunmuş olurlar. Giddens, yeni doğan bir bebek ve bakıcısı arasındaki güven oluşumunun, rutinler ve alışkanlıklara bağlı olduğunu düşünmekte; bu rutinlerin bebeğin kimlik oluşumunu sağladığını ve kendisine koruyucu bir koza oluşturduğunu belirtmektedir. Bebek için ontolojik güvenliğin kaynağı bu kozadır ve bu koza onun ilerideki yaşamına etki eder. ${ }^{26}$ Güneşin her sabah doğudan doğup, batıdan batması gibi önceden bilinir, doğaya ait rutinlerin tekrarı, insanlara fiziksel olarak güvende olma duygusu sağlarken;

${ }^{25}$ Croft, Securitizing Islam..., s. 17.

${ }^{26}$ Giddens, birey-güvenlik ilişkisinin küçük yaşlardan itibaren başladığına dair Maslow'la örtüşmektedir. Maslow'a göre, yaşamının ilk yıllarından itibaren deneyimlenen kötü tecrübeler ve yeterince giderilmemiş temel ihtiyaçlar, insanda güvende olmadığı yönünde duygular yaratır. Bu duygular eşliğinde insan, dış dünyayı ve onun içinde yer alan diğer insanları kendisine yönelmiş bir tehdit/tehlike olarak algılar. Detaylar için bkz. Abraham H. Maslow, "The Dynamics of Psychological Security-Insecurity", Character \& Personality; A Quarterly for Psychodiagnostic \& Allied Studies, 1942, Cilt: 10, 331-344. 
Uluslararası İlişkiler Disiplininde Ontolojik Güvenlik Teorisi:

Kavram ve Literatür Odaklı Bir İnceleme

bunun tersini düşünmek, diğer bir deyişle "belirsizliklerle kuşatılmışlık duygusu", insanı kaygıya sürükleyebilmektedir. Fiziksel güvenliğe ihtiyaç duyan ancak aynı zamanda sosyal bir varlık olan insanlar, sosyal etkileşimlerinde rutin davranış kalıpları benimseyerek, kaygılardan uzaklaşmakta; bu rutinlerle öz-kimliklerini muhafaza etmekte, dolayısıyla da varlıklarına dair tüm benlik/kimlik unsurlarını içeren olguları korumaya çalışmaktadır. Bu niteliğiyle ontolojik güvenlik; "fiziksel güvenlik" ile "var-olma olarak güvenlik (veya benlik/kimlik güvenliği)" arasındaki farkı ortaya çıkarmakta; ikinciye yapılan vurguyu arttırmaktadır. ${ }^{27}$

Ontolojik güvenlik, "günlük hayat rutinleriyle" birebir ilişkilidir. McSweeney, ontolojik güvenlik kavramının kökenlerinin günlük hayat rutinleriyle yakından ilgilenen Husserl, Schutz, Goffman ve Garfinkel'e dayandığını düşünmektedir. ${ }^{28}$ Her gerçekliğin ve olayın bir özü olmasından hareket ederek, bir öz ontolojisi olan "fenomenoloji" kuran Husserl, ${ }^{29}$ bu yöntemle varoluşçu felsefe ve "yeni ontoloji"nin zeminini hazırlamış; ${ }^{30}$ Schutz ise Husserl'in fenomenoloji kavramıla Weber sosyolojisi arasında eleştirel bir sentez yaparak, gündelik hayat rutinlerine ve sosyal etkileşime odaklanmıştır. ${ }^{31}$ Schutz'dan etkilenen Garfinkel ise, "etnometodoloji"yi temellendirerek, inşa edilen günlük hayat rutinlerinin arkasındaki gerçekliği ortaya çıkarmaya çalışmıştır. ${ }^{32}$ Goffman ise bu

${ }^{27}$ Detaylar için bkz. Helin Sarı Ertem, "Kimlik ve Güvenlik İlişkisine Konstrüktivist Bir Yaklaşım: 'Kimliğin Güvenliği' ve 'Güvenliğin Kimliği' ”, Güvenlik Stratejileri Dergisi, 2012, Cilt:16, Cilt: 16, 177-234.

${ }^{28}$ Bill McSweeney, Security, Identity and Interests: A Sociology of International Relations, Cambridge University Press, Cambridge, 1999, s. 154.

${ }^{29}$ Edmund Husserl, Phenomenology and the Crisis of Philosophy, Harper \& Row, New York, 1965, s. 2.

30 Ülker Öktem, "Fenomenoloji ve Edmund Husserl'de Apaçıklı (Evidenz) Problemi", Ankara Üniversitesi Dil ve Tarih-Coğrafya Fakültesi Dergisi, 2005, Cilt:45, Sayı: 1, 27-55, ss. 28-29.

${ }^{31}$ Alfred Schutz, The Phenomenology of the Social World, Northwestern University Press, London, 1967, ss.18-20, ss. 151-155.

${ }^{32}$ Etnometodoloji, olağandışı gelişmelere ve/veya sürekliliklere odaklanan sosyolojide göz ardı edilen, bireylerin günlük rutinlerinin arka planını araştırmaktadır. Böylelikle gündelik yaşama ait rutinlerin ardında saklanan, inşa edilmiş gerçeklerin ortaya 
çalışmaları takip ederek gündelik hayat rutinlerini, insanlar arasındaki yüz yüze etkileşimi ve bir tiyatro sahnesi olarak nitelediği yaşamda insanların sosyal rollerini kimlikleri üzerinden incelemektedir. ${ }^{33}$ Laing de ontolojik güvenliği ve ontolojik anlamda güvende olan bireyi tanımlarken "sürekliliğe" ${ }^{34}$ dikkat çekmiş; Giddens ${ }^{35}$ ise -yine Goffman ve Garfinkel'den alıntılarla- "rutinlere" vurgu yapmıştır.

Birey düzeyinde ontolojik güvenlik, insanların kendi biyografik öz-anlatılarının, yerleşik davranış kalıplarının ve günlük yaşam aktivitelerinde onlara güven veren sosyal ilişkilerinin istikrarına dayanmaktadır. ${ }^{36}$ Günlük yaşama dair biyografik-anlatılarda ve sosyal etkileşimlerde süreklilik arz eden rutinler, önceden bilinir ve tahmin edilebilir oldukları için "güven" hissi vermektedir. Diğer bir deyişle, kendi-içinde ve etrafinda neler olduğunu bilen veya ilerleyen zaman içinde ne olabileceğini tahmin edebilen bireyde oluşan kontrol hissi, onu belirsizliklerden korumaktadır. ${ }^{37} \mathrm{Bu}$ rutin davranış kalıpları işle, evle, dini inançla, sosyal etkileşimlerle ya da ulusal kimlikle ilişkili olabilir. ${ }^{38}$ Giddens'ın tanımıyla: "rutinleşme, psikolojik mekanizmalar için hayati öneme sahiptir; sosyal hayatın günlük yaşam aktivitelerindeki güven duygusu ya da ontolojik güvenlik, rutinleşme sayesinde sürdürülmektedir."39 "Rutinleri aktörler ortaya çıkarır, sürdürür, değiştirir ve bu rutinler, Goffman'ın tabiriyle koşullar veya diğer aktörler tarafından tehdit edildiğinde ise onarılır." 40

çıkarılma amacı güdülmektedir. Bkz. Harold Garfinkel, Studies in Ethnomethodology, Prentice Hall, New Jersey, 1967.

${ }^{33}$ Erving Goffman, Encounters: Two Studies in the Sociology of Interaction, Penguin University Books, 1972, ss. 7-13.

${ }^{34}$ Laing, The Divided Self..., s. 39, ss. 41-42.

${ }^{35}$ Giddens, Modernity and Self-Identity..., ss. 56-58.

${ }^{36}$ Rumelili ve Adısönmez, "Uluslararası İlişkilerde Kimlik Güvenlik..., s. 3.

${ }^{37} \mathrm{McS}$ weeney, Security, Identity and Interests ..., ss. 154-155.

${ }^{38}$ Croft, Securitizing Islam..., s. 17.

${ }^{39}$ Giddens, The Constitution of Society..., s. xxiii.

${ }^{40}$ Erving Goffman, Interaction Ritual: Essays on Face-to-Face Behaviour, Anchor Books, 1967, s. 135. Akt. McSweeney, Security, Identity and Interests..., s. 156. 
Uluslararası İlişkiler Disiplininde Ontolojik Güvenlik Teorisi:

Kavram ve Literatür Odaklı Bir İnceleme

Giddens'a göre, insanlar ontolojik güvenlik ihtiyacı nedeniyle rutinleri hayatlarına yerleştirirken aynı zamanda sosyalleşerek gelecek nesillere de aktarmaktadır. ${ }^{41}$ Sosyal düzenin, rutinlerle istikrar kazandığını düşünen ${ }^{42}$ Giddens, ontolojik güvenliğin refleksif (özdönüşümsel) bilinçlenmeye dayandığını öne sürmektedir. ${ }^{43}$ Buna göre, ontolojik güvenliğin, özneyi sürekli olarak bilinçli hareket etmeye yönelten bir yanı vardır. Giddens öz-kimliği, insanların özelliklerinin toplamından çok, bireylerin kendi yaşam öykülerinde yine kendileri tarafından anlaşılmış öz-benlikleri olarak tanımlamaktadır. Bu nedenle biyografik-anlatıların devamlılı̆̆1, diğer insanlarla etkileşimler ve rutinler, ontolojik güvenliğin temel öğeleridir. ${ }^{44}$ Ontolojik güvenliği sağlayan rutinler ve alışkanlıklar bozulduğunda bireylerin karşılaştıkları belirsizlik, kararsızlık ve kaygı, ontolojik güvensizlik hali yaratmaktadır.

\section{Ontolojik Güven(siz)likte "Kaygı"nın Yeri}

Giddens için ontolojik anlamda güvensiz birey, varlığını devam ettirme konusunda sürekli bir kaygı taşımaktadır. Bu nedenle de yazara göre ontolojik güvensizliği açığa çıkaran asıl duygu kaygıdır. Korku ve kayg1 arasındaki farkl11ıkları tanımlayan Giddens, korkunun belirli bir tehdide cevap niteliğinde olduğunu ve bu nedenle net bir amaç taşıdığını söylemektedir. Kaygı ise, korku nesnesi gibi bir nesnesi olmayan, hatta nesneyi göz ardı eden bir yapıya sahiptir. Korku harekete geçirirken, kayg1 hareketsiz bırakır. Kayg1 arttıkça öz-kimlik bilinci tehdit edilmektedir. Belirsizlik kaygıya neden olurken, devamında sırasıyla öfke patlaması ve ötekileştirme getirebilir. ${ }^{45}$ Giddens, kaygıyla ilgili teorileştirmesini Kierkegaard'dan almıştır. Kierkegaard kaygıyı psikolojik bir analize tabi tuttuğu, Kaygı Kavramı kitabında, korku ve kayg1

\footnotetext{
${ }^{41}$ Engin Yıldırım, "Anthony Giddens'ın Yapılanma Teorisi”, Bilgi Sosyal Bilimler Dergisi, 1999, Cilt: 1, 25-44, s. 37.

${ }^{42}$ Ian Craib, Anthony Giddens, Routledge, New York, 2011, s. 106.

${ }^{43}$ Yildırım, "Anthony Giddens'1n...", ss. 37-38.

${ }^{44}$ Rumelili, "Ontological (In)security and Peace Anxieties..., s.11.

${ }^{45}$ Giddens, Modernity and Self-Identity..., s. 43-46.
}

Güvenlik Stratejileri

Cilt: 17

Say1: 37 
Güvenlik Stratejileri

Cilt: 17

Sayı: 37

kavramları arasındaki farklılı̆̆a odaklanmaktadır. Kierkegaard'a göre, kaygının nesnesi korkununkinden farklı şekilde, "hiçlik"tir; başka bir deyişle insanlar "gerçekte var olmayan şeyler uğruna kaygılanırlar." Kierkegaard'ın belirsizlik temalı bu duyguya dair düşünceleri, 14. yüzy1l Doğu bilgelerinden Hâfız-1 Şîrâzî’nin "gönül; bir damla kan ve binlerce endişe" sözünü hatırlatmaktadır. ${ }^{47}$ İnsan yapısı gereği, binlerce kaygı taşımakta; istese de bu duygudan kurtulamamaktadır. Kierkegaard'a göre insan kaygıdan kaçmak istese de kaçamaz, onu sevmeye çalışsa da sevemez; ancak bu duygu, varlığının değişmez bir unsurudur. ${ }^{48}$

Kierkegaard'da kayg1 insanın gelişimine açılan "özgürlüğün başdönmesi",49 iken, Giddens'ta kaygı aşırı bir durum olan kaosla eşittir. Giddens, ontolojik güvenlik sağlanamadığında; diğer bir deyişle ontolojik güvensizlik durumunda ortada bir kaos hali olduğunu ileri sürmekte; buna ilaveten kaosu, varoluş anlayışımızın kaygılar tarafından istila edilme olasılığ 1 olarak tanımlamaktadır. ${ }^{50} \mathrm{Bu}$ tarz kaotik durumların, gündelik rutinlerin yeniden üretilmesiyle aşılabileceğini öne süren Giddens'a göre bireyler, tıpkı içinde yaşanılan dünyada var olan nesnelerin süreklilik sağlayan rutinleri gibi, kendi sosyal hayatlarında da kaygıları ortadan kaldıracak devamlılıklar inşa eder. Buna göre birey, ilk etapta çeşitli kontrol mekanizmalarıyla ortaya çıkan kaygıyı kontrol etmeye çalışacak; bu olmazsa ontolojik güvensizlik içine girecektir. Bireyin süreklilik ve tutarlılık duygusunu kaybetmesi halinde, bunun bir öz-kimlik krizi haline gelmesi mümkündür. ${ }^{51}$ Bireysel ya da toplumsal travmalar ise, ontolojik güvensizliğin en radikal hali olarak kabul edilmektedir. ${ }^{52}$

${ }^{46}$ Soren Kierkegaard, Kaygı Kavramı, (Çev. Türker Armaner), Türkiye İş Bankası Kültür Yay., İstanbul, 2013, s. xi, ss.35-37.

47 "Yek katre-i hunest ve hezar endișe" Bkz. Hâfiz-1 Șîrâzî, Sark İslam Klasikleri Hafiz Divanı Şirazî, (çev. Abdülbaki Gölpınarlı), MEB Yayınları, İstanbul, 1992, s. 545.

${ }^{48}$ Kierkegaard, ss.35-37.

${ }^{49}$ A.g.e., ss. 56 .

${ }^{50}$ Giddens, Modernity and Self-Identity..., s. 36-37.

${ }^{51}$ Ejdus, Crisis and Ontological..., s. 8.

${ }^{52}$ Steele ve Innes, "Memory, Trauma and...", s. 15. 
Uluslararası İlişkiler Disiplininde Ontolojik Güvenlik Teorisi:

Kavram ve Literatür Odaklı Bir İnceleme

Kaygı konusu, tıpkı, kimliğe dair "öteki inşası" tartışmalarında olduğu gibi, daha çok negatif unsurlarıyla öne çıksa da kaygının pozitif etkilerinin göz ardı edilmemesi gerektiğini düşünen yazarlar da vardır. $\mathrm{Bu}$ yazarlara göre, aslında insan için sonsuz olasılıklar arasında seçim yapma özgürlüğü sağlayan unsur, kaygıdır. Giddens'1, kavramı (özellikle negatif yönüyle) aşırılaştırdığ 1 düşüncesiyle eleştiren Rumelili, derlediği Conflict Resolution and Ontological Security adlı kitabında kaygıyı, çatışma çözümünde olumlu/olumsuz etkileriyle anahtar bir kavram olarak ele almakta; farklı kavramlar oldukları halde, Uİ disiplininde kaygı ve korku arasındaki ayrımın yeterince vurgulanmadığını ve kaygının, toplumlar/devletlerarası çatışmaların çözümünde "duygusal dönüm noktası" olduğunu öne sürmektedir. ${ }^{53}$ Yazar, Kierkagaard ${ }^{54}$ ve Heidegger'den ${ }^{55}$ alıntılarla, bireyin varoluşunu gerçekleştirmek için farklı alternatifler arasında seçim yapma yetisinin, kaygıların getirdiği belirsizlik sayesinde geliştiğini düşünmektedir. ${ }^{56}$ Giddens'ın kaygı kavramsallaştırmasını eleştiren ve farklı bir bakış açısı sunan başka bir iddia da Karl Gustafsson ve Nina Krickel-Choi tarafindan sunulmuştur. ${ }^{57}$ Gustafsson ve Krickel-Choi, Laing'in de ilham aldığı varoluşçu teorisyenlere tekrar dönerek, Rollo May'in "normal ve nevrotik kaygı" ayrımını yeniden ele aldıkları çalışmalarında, Giddens'1 kaygı düzeylerindeki farklılaşmayı reddetmesiyle ve ontolojik güvensizliği normal kaygı düzeyiyle eşitlemesiyle eleştirmektedirler. Rollo May'in kaygı kavramsallaştırmasından yola çıkan yazarlara

\footnotetext{
${ }^{53}$ Rumelili, “Ontological (In)security...”, s. 13.

${ }^{54}$ Kierkegaard'a göre: "Kayg1, özgürlüğün olanağıdır" ve "kişinin istediği yere gitmesine izin verir" Bkz. Kierkegaard, s. xi, ss. 156-159.

${ }^{55}$ Heidegger'e göre kaygı Dasein'ı özgürleştirerek, seçim şansı verir ve olanaklarını gerçekleştirmesine imkân sağlar. Bkz. Martin Heidegger, Being \& Time, (Çev. J. Macquarrie \& E. Robinson), Blackwell Publishers, Oxford, 1962, s. 232, s. 315.

${ }^{56}$ Rumelili, "Ontological (In)security...", s. 11-12.

${ }^{57}$ Ek olarak Mitzen ve Kinnvall'un korku/ kaygı ayrımına, Giddens'ın perspektifinin sınırlılıklarına dair yeni makalesi için bkz. Catarina Kinnvall \& Jennifer Mitzen, "Anxiety, Fear, and Ontological Security in World Politics: Thinking With and Beyond Giddens", 2020, International Theory, 12(2), 240-256.
}

\section{3}

Güvenlik Stratejileri

Cilt: 17

Say1: 37 
Güvenlik Stratejileri

Cilt: 17

Sayı: 37

göre, "normal kaygı" herkes tarafından belli bir düzeye kadar yaşanma ihtimali olan bir duyguyken; nevrotik kayg1, zayıflatıcı ve engelleyici bir etkiye sahiptir. Kontrol altına alınamayan bu patolojik durum, kontrol altına alınabilen normal kaygı düzeyinden farklılaştırılmakta ve ontolojik güvensizliğe dair tanıma yeni bir pencere açmaktadır. ${ }^{58}$

Hali hazırda inşa olmaya devam eden ve diğer Uİ teorilerinde de görülen şekilde kendi içinde tartışmalar barındıran ontolojik güvenlik literatürü, bulunduğu aşamada kendi içinde farklı perspektifler sunmaktadır. Uİ disiplininde ontolojik güvenlik temelli çalışmaların artmasıyla birlikte, aktörleri daha çok devletlerden oluşan pek çok ulusal ve uluslararası meselede, ontolojik güvenlik ve güvensizlik tartışmaları yapılmış; güvenlik çalışmaları bu sayede farklı ve zengin bir analiz aracı daha kazanmıştır. Çalışmanın devam eden bölümleri, disiplinde ontolojik güvenlik tartışması baz alınarak yapılan, farklı uluslararası çalışmaları incelemektedir.

\section{Ui Yazınında Ontolojik Güvenlik Teorisi (OGT)}

Eleştirel güvenlik çalışmalarının, 1990'lı yıllardan itibaren, güvenlik sorunlarını salt askerî boyutla açıklama geleneğini sorgulamaya başlaması, ontolojik güvenlik yaklaşımını harekete geçiren itici güçlerden biri olmuştur. Eleştirel güvenlik çalışmalarına dâhil olan ontolojik güvenlik yaklaşımlı araştırmalar, realizmin baskın etkisiyle, devletlerin güvenliğinin fiziksel güvenliğe hapsolmasını; güvenliğin tehlike, tehdit ve beka gibi kavramlarla sinırlandırılarak tanımlanmasını eleştirmektedir. ${ }^{59}$ Görüldüğü üzere, ontolojik güvenliğin odağı, sadece

${ }^{58}$ Karl Gustafsson ve Nina C. Krickel-Choi. "Returning to the Roots of Ontological Security: Insights from the Existentialist Anxiety Literature", European Journal of International Relations, 2020, 1-21, ss. 1-3.

${ }^{59}$ Bahar Rumelili ve Sibel Karadağ, "Göç ve Güvenlik: Eleștirel Yaklaşımlar", Toplum ve Bilim, 2017, Cilt: 140, 69-92, s.72. Huysmans ise, ontolojik güvenlik odaklı "yeni güvenlik çalışmaları" literatürüne özellikle "kaos ve düzen" unsurlarını öne çıkaran tartışmalarıyla katkıda bulunmuş̧ur. Bkz. Jef Huysmans, "Security! What Do You Mean?: From Concept to Thick Signifier", European Journal of International Relations, 1998, Cilt: 4, No: 2, 226255, ss. 226-229. 
Uluslararası İlişkiler Disiplininde Ontolojik Güvenlik Teorisi:

Kavram ve Literatür Odaklı Bir İnceleme

somut, fiziksel anlamı değil, iç-kaynaklı-varlığa dair tüm soyut anlamları da kapsayacak bir istikrar ve devamlılıktır. Fiziksel güvenlik tanımını sorgulayan ontolojik güvenlik, en yalın tanımıyla "kimliğin/benliğin/içkaynaklı varlığın güvenliğ̈i" ${ }^{\circ 0}$ demektir ve bu güvenlik çeşidi biyografik anlatının istikrarının sağlanması anlamına gelmektedir.

Bireyden devlet düzeyine geçildiğindeyse ontolojik güvenlik, o devletin kendi varlığının önemli bir parçası olarak gördügü tüm içsel unsurlarının tehlikeden ve belirsizlikten uzak olmasını ifade eder. Uİ disiplininde ontolojik güvenlik çalışan uzmanlar, ağırlıklı olarak devlet davranışlarına, kimliklerine/benliklerine/iç-kaynaklı varlıklarına ve devletlerarası ilişkilere odaklanarak, devlet anlatılarının ve davranışlarının nasıl rutin hale geldiğine bakmış; ayrıca bu anlatıların çoğu zaman kendilerine ve ötekilere ait imgelerle bağlantılı bir şekilde tekrar eden çatışmalara nasıl kaynaklık ettiğini açıklamaya çalışmışlardır. ${ }^{61}$ Innes ve Steele'ye göre, Uİde ontolojik güvenlik, devletlerin “....kim veya ne olduğu ya da ne istediği ile ilgili yürütülen; devlet kimliğinde sürekliliklere ve kimliği/iç-kaynaklı-varlığı tehdit edebilecek unsurlara odaklanan bir güvenlik araştırması şeklidir." ${ }^{62}$ Devletlerin kendilerini ontolojik anlamda güvende hissetmelerinin asli unsurları ise biyografikanlatılarının sürekliliği ve diğer devletlerle ilişkilerindeki rutinlerdir.

Ontolojik güvenlik kaynağının içsel veya dışsal etkileşimlere bağlı olup olmadığı konusu kendi literatürü içerisinde ayrıca bir tartışma konusu olmuştur. ${ }^{63}$ Ontolojik güvenlik çalışanlar arasında tercih edilen "benlik" (the self), "kimlik" (identity) ve/veya "var olma-olarak-güvenlik" (security-as-being/security of being) kavramları farklı çalışmalarda farklı sonuçlar doğurmakta ve bu farklılaşma bir belirsizliğe neden olduğu için eleştirilmektedir. Jennifer Mitzen, ontolojik güvenliği "benliğin

\footnotetext{
${ }^{60}$ Detaylar için 15. dipnota bakınız.

${ }^{61}$ Örn. bkz. Catarina Kinnvall ve John Cash, "Postcolonial Bordering and Ontological Insecurities", Postcolonial Studies, 2017, Cilt: 20, No: 3, 267-274, s. 269.

${ }^{62}$ Steele ve Innes, "Memory, Trauma and...", s. 15.

${ }^{63}$ May Darwich, Threats and Alliances in the Middle East: Saudi and Syrian Policies in a Turbulent Region, Cambridge University Press, United Kingdom, 2019, s. 35.
}

55

Güvenlik Stratejileri

Cilt: 17

Say1: 37 
Güvenlik Stratejileri

Cilt: 17

Sayı: 37

güvenliği”" ${ }^{64}$ olarak açıklarken, dışsal-sosyal etkileşime benlikte kurucu rol vermektedir. Bahar Rumelili ise bu tanımlamanın diğer eleştirel güvenlik kavramsallaştırmalarından farkını ortaya koyamadığını ve benlik ile kimlik güvenliği arasındaki ayrımın görünmezliğinin, Ui literatüründe belirsizlik yarattığına dikkat çekmektedir. ${ }^{65}$ Mitzen'in sosyal etkileşim vurgusunu eleştirerek ontolojik güvenliği "iç-kaynaklı varlığa ait bir diyalektik" olarak açıklayan Rumelili, kavramın tanımını McSweeney, Steele ve Kinnvall ile benzer șekilde "var-olma-olarak güvenlik" şeklinde yapar. ${ }^{66}$ Buna ek olarak Kinnvall, "içselleştirilmiş benlik kavramlarının ben-öteki temsillerinin ayrılmaz bir parçası olduğunu ve sosyal etkileşimle uyumlu olduğunu" ${ }^{, 67}$ iddia etmektedir. Filip Ejdus ise, benlik-kimlik ayrımını vurgulayarak, aktörlerde kimliklerin birden fazla olabileceğinden ve benliğin istikrarının sağlanması için kimliğin değişebilir karakterinden bahsetmektedir. ${ }^{68}$ Ontolojik güvenlik literatüründe farklı çalışmaların zeminini oluşturan bu üç kavram (benlik/kimlik/var-olma-olarak güvenlik) hali hazırda bir tartışma konusu olmaya devam etmektedir.

Burada önemli olan bir başka husus bu rutinlerin ya da devletin yine rutinlerle inşa ettiği kimliğin/benliğin/iç-kaynaklı varlığın diğerleri tarafından tanınmasıdır. Devletleri de bireyler gibi iç-kaynaklı varlığa sahip sosyal aktörler addeden ontolojik güvenlik teorisi, çıkar tanımlarını ve tehdit algılarını oluşturan bu varlıklarının, devletlerin kendilerini

${ }^{64}$ Mitzen, "Ontological Security..., s. 344.

${ }^{65}$ Detaylar için bkz. Rumelili ve Adısönmez, "Uluslararası İlişkilerde Kimlik Güvenlik..., s. 4; Rumelili, "Identity and Desecuritization...", s. 2.

${ }^{66}$ Detaylar için bkz. McSweeney, Security, Identity and Interests..., s. 157; Catarina Kinnvall, "Feeling Ontologically (In)secure: States, Traumas and the Governing of Gendered Space", Cooperation and Conflict, 2016, Cilt: 52, No: 1, 90-108, s. 1, ss. 7-8; B. J. Steele, Ontological Security in International Relations: Self-Identity and the IR State, Routledge, New York, 2008, s. 32, ss. 50-51.

${ }^{67}$ Akt. May Darwich, Threats and Alliances in the Middle East: Saudi and Syrian Policies in a Turbulent Region, Cambridge University Press, United Kingdom, 2019, s. 35. Detaylar için bkz. Catarina Kinnvall, "Globalization and Religious Nationalism: Self, Identity..., s. 749. ${ }^{68}$ Ejdus, Crisis and Ontological Insecurity... 
tanıma, tanımlama ve temsil etme özelliklerinin yanı sıra, bu tanımların diğer devletler tarafından kabul görüp görmediğine bağlı olarak oluştuğuna da dikkat çekmektedir. Dolayısıyla bu bakış açısıyla bir devletin iç-kaynaklı-varlığı, onu bir diğerinin tanıması/kabulü ile de birebir bağlantılıdır. Mitzen, bir devletin, ötekiler de onu aynı şekilde tanımlamadığı sürece, sahip olduğunu iddia ettiği benliği sürdüremeyeceğini öne sürmekte; hatta tam tersine, sirf ötekiler onu öyle tanımlıyor diye, zamanla olmadığını iddia ettiği bir rol kimliğine bürünebileceğini iddia etmektedir. Bu perspektifle bakıldığında devletler arasındaki sosyal etkileşim, devletin iç-kaynakl1-varlığını "inşa edici" bir göreve sahiptir. ${ }^{69}$ Tıpkı ontolojik güvenlik yaklaşımı gibi, yine psikolojiden Uİ disiplinine aktarılan Goffman'ın "Damgalama" (Stigmatization) teorisi de uluslararası camia tarafindan belirli olumsuz niteliklerle damgalandıklarında, bazı devletlerin buna direndiğini ve tersini ispat etmeye çalıştı̆̆ını; diğer bazı devletlerin ise (sahip olduklarını iddia ettikleri kimliklerin tam tersi olan) bu damgayı ya da etiketi kabullendiğini ve buna uygun hareket etmeye başladığını ortaya koymaktadır. ${ }^{70}$

Birey, grup, toplum ve devlet düzeylerinde rutinler, sosyal etkileşimler, kaygı ve istikrarla doğrudan bağlantılı olan OGT literatüründe, farklı yazarlar tarafindan yapılan çalışmalar bir sonraki bölümde geniş bir literatür taramasıyla ortaya koyulacak; özellikle de Kinnvall, Mitzen ve Steele'nin eserlerine yer verilecektir. Türkiye'de bu konuda yapılan az sayıdaki çalışmaya da yine bu bölümde dikkat çekilecektedir.

\subsection{OGT'de Öncül Çalışmalar}

Uİ'de ontolojik güvenlik yaklaşımına dair öncül çalışmalar, Huysmans, McSweeney ve Manners'a aittir. Güvenliği "yoğunlaşma" (thickening) kavramı üzerinden açıklamaya çalışan Huysmans'a göre

\footnotetext{
${ }^{69}$ Mitzen, “Ontological Security...”, s. 358.

70 Ayrıntılar için bkz. Rebecca Adler Niessen, "Stigma Management in International Relations: Transgressive Identities, Norms, and Order in International Society", International Organization, 2014, Cilt: 68, No: 1, 143-176 ve Erving Goffman, Stigma: Notes on the Management of Spoiled Identity, Prentice-Hall, New Jersey, 1963.
}

\section{7}

Güvenlik Stratejileri

Cilt: 17

Say1: 37 
Güvenlik Stratejileri

Cilt: 17

Sayı: 37

aktörlerin karşı karşıya oldukları korkulardan biri belirsizlikler içeren koşullarla ilgilidir. Bu korku da aktörlerde istikrarlı bir ortama duyulan ihtiyacı artırarak, içinde bulundukları çevreyi tanımayı ve kategorize etmeyi gerektirmekte, diğer bir deyişle, öteki aktörlerle işbirliği veya çatışma halinde olma durumlarını değil, var olan tüm koşulların tanınmasını ve öngörülebilir olmalarını önceleyen bir formül sunmaktadır. Huysmans güvenliğin "beka" (survival) olarak algılanışını, bir sosyal ilişki öngörme stratejisi olarak tanımladığı ontolojik güvenlik anlayışından ayırmıştır. ${ }^{71}$ Benzer şekilde McSweeney de ontolojik güvenlik kavramını Kopenhag Okulu'nda geliştirilen toplumsal güvenlik kavramına göre daha refleksif (öz-dönüşümsel) bir alternatif olarak önermiştir." 72 Bireylerde varlıklarının güvenliklerini sağlama ve sürdürme güdüsünün küçük yaşlardan itibaren bilinçsiz bir şekilde var olduğunu söyleyen McSweeney'e göre ontolojik güvenlik, bireylerin sosyalleşme ihtiyacına cevap verebilecek güvene ve güvenilir ilişkilere dayanmaktadır. Nietzsche'ye atıfla bireyin "aşina olunana olan ihtiyacını" rutinler üzerinden anlatan yazar, ontolojik güvensizliği ise kolektif kimlik duygusunun bozulmasıyla ilişkilendirmektedir. ${ }^{73}$

Çalışmasında Avrupa Birliği’nin (AB) ontolojik güvenlik tehdidi olarak görülmesinin kurumu güvenlikleştirmeye yol açtığını belirten Manners ise ilk kez 2002'de Kopenhag Okulu'nun güvenlikleştirme tipolojisi içinde var olan öznel/nesnel ve varllksal (existential) / ontolojik (varoluşsal) ayrımlarını tartışırken, ontolojik güvenliğe atıflarda bulunmaktadır. Güvenliğin genişlemesi (broadening), derinleşmesi

${ }^{71}$ Akt. Ejdus, Crisis and Ontological Insecurity..., s. 10; Jennifer Mitzen, "Ontological Security in World Politics, and Implications for the Study of European Security", CIDEL Workshop, 2004, 1-52, s. 16, Ayrıntılar için bkz. J. Huysmans, "Security! What Do...", s. 229, s. 242.

${ }^{72}$ Ejdus, Crisis and Ontological Insecurity..., s. 10. Ayrıntılar için bkz. McSweeney, "Identity and Security: Buzan and the Copenhagen School", Review of International Studies, Say1: 22, No: 1, 1996, 81-93; B. McSweeney, "Durkheim and the Copenhagen School: A Response to Buzan and Wæver", Review of International Studies, Say1: 24, No: 1, 1998, 137-140; B. McSweeney, Security, Identity and ...

${ }^{73}$ B. McSweeney, Security, Identity and Interests..., ss.154-156. 
Uluslararası İlişkiler Disiplininde Ontolojik Güvenlik Teorisi:

Kavram ve Literatür Odaklı Bir İnceleme

(deepening) ve anlamının yoğunlaşmasına (thickening) ek olarak, dinamik bir şekilde yön vericiliğine vurgu yapan "vectoring" kavramını ortaya atan Manners, Kopenhag Okulu'ndan Buzan, Waever ve Wilde gibi güvenliğin nesnel olmak yerine öznel, durağan olmak yerine değişken ve dinamik bir süreç olduğunu iddia etmiştir. ${ }^{74}$ UI'de ontolojik güvenlik, kavramsal olarak ilk kez yukarıda bahsi geçen, Huysmans, McSweeney ve Manners'in eserlerinde yer almış olsa da, bu kavramın bir teoriye dönüştürülmesinde öne çıkan isimler Kinnvall, Mitzen ve Steele'dir. Devam eden bölüm, bu yazarların başlıca eserlerini analiz değerlendirecektir.

\subsection{Ui'de OGT'nin Kinnvall, Mitzen ve Steele ile Gelişimi}

Gustaffson, Browning, Mälksoo, Ejdus, Croft, Lupovici, Rumelili, Subotic, Zarakol, Berenskoetter, Darwich, Krolikowski ve Cash gibi pek çok akademisyen OGT literatüründe eserler verse de bu incelemeye adı geçen yazarların tüm çalışmalarını ve tartışmalarını sığdırmak imkânsızdır. Bu nedenle de kavramın diğer yaklaşımlardan farklılaşarak bir teori haline gelmesini sağlayan isimler oldukları için, çalışma temelde Kinnvall, Mitzen ve Steele'ye odaklanarak, güvenlik çalışanların bu yazarlarca alana yapılan katkıyı keşfetmesi amaçlamıştır.

$\mathrm{Bu}$ üç isimden ilk ele alacağımız araştırmacı olan Catarina Kinnvall, 2000'lerde milliyetçilik, küreselleşme, kolektif kimlikler ve din/inanç üzerine araştırmalarıyla ünlenmiş; ontolojik güvenlik kavramını ise özellikle siyaset psikolojisi alanında verdiği eserlerde kullanmıştır. Hindistan özelinde kimlik inşaları, ötekileştirme süreçleri, seçilmiş toplumsal travmalar üzerine pek çok çalışmaya imza atan Kinnvall, 2004'te yayımladığı "Globalization and Religious Nationalism: Self, Identity, and the Search for Ontological Security" başlıklı makalesinde belirsizliklerin ve bilinmeyen tehditlerin, küreselleşmenin etkisiyle gittikçe arttığı bir ortamda, yoğun bir güvensizlik yaşandığını

\footnotetext{
74 Ian Manners, "European [Security] Union from Existential Threat to Ontological Security”, Kopenhag Barış Araştırmaları Enstitüsü (COPRI), Cilt: 42, 2002, 1-43, ss. 8-12.
} 
60

Güvenlik

Stratejileri

Cilt: 17

Sayı: 37

vurgulamaktadır. ${ }^{75}$ Kinnvall'a göre artan bu ontolojik güvenlik ihtiyacı kolektif kimliklere aidiyetle giderilmektedir. Ontolojik güvenliğe ulaşmak için, din ve milliyetçilik özellikle tercih edilen kimlik belirteçleridir ve bu belirteçler, herhangi bir aidiyeti olmayan, belirsizlik ve yüksek kaygı halindeki insanlara, adeta bir başlarını sokacak bir ev sunmaktadır. Kinnvall, aynı yıl yayınlanan bir başka kitap bölümünde ise Erikson'un ontolojik güvensizlik ve varoluşsal kaygı tanımlarını incelemekte ve kimlik çatışmalarında var olan bileşenler fark edilirse, çatışma çözümüne katkı sağlanacağını iddia etmektedir. ${ }^{76}$

Kinnvall, 2006'da çıkan Globalization and Religious Nationalism in India: The Search for Ontological Security isimli kitabında ise Sih ve Hindu kimlikleri üzerinden, kimlik çatışmalarına dair karşılaştırmalı bir analiz yapmıştır. ${ }^{77}$ Yazar bu bağlamda, "teröre karşı savaş" ve "çok kültürlülük" gibi kavramlarla, küreselleşme, din ve milliyetçilik arasındaki ilişkiye odaklanarak; kimlik inşa süreçleriyle ontolojik güvenlik arasında var olduğunu düşündüğü güçlü bağı ortaya koymaya çalışmaktadır. Yazar, özellikle 11 Eylül olayları sonrası dönemin istikrarsız ve belirsiz ortamında Hindistan'da yükselen dini ve milliyetçi söylemlerin, güvensizliğe karşı adeta bir koruma kozası işlevi gördüğünü; bunun da toplumsal bir dönüşüme sebep olduğunu öne sürmektedir. $\mathrm{Bu}$ çerçevede Kinnvall, Hindistan özelinde, öz-benlik, kimlik, "öteki"lerin inşası, güvenlik, grupların mobilizasyonu ve küreselleşmenin insanlar üzerindeki

${ }^{75}$ Catarina Kinnvall, "Globalization and Religious Nationalism: Self, Identity...", ss. $741-744$ ve s.763.

${ }^{76}$ Catarina Kinnvall, "Globalization, Identity, and the Search for Chosen Traumas", Kenneth Hoover (ed.), The Future of Identity: Centennial Reflections on the Legacy of Erik Erikson, Lexington Books, Oxford, 2004, 111-136, s. 112. Ayrıca bkz. Erik H. Erikson, Childhood and Society, Paladin Books, London, 1977; Erik H. Erikson, Identity and the Life Cycle, W.W. Norton\&Company, New York, 1959; Erik H. Erikson, Insight and Responsibility: Lectures on the Ethical Implications of Psychoanalytic Insight, W.W. Norton \& Company, 1964; Vamık D. Volkan, Bloodlines: From Ethnic Pride to Ethnic Terrorism, Basic Books, 1998; Julia Kristeva, Powers of Horror: An Essay of Objection, University Presses of California, Columbia and Princeton, 1982.

${ }^{77}$ Kinnvall, Globalization and..., ss. 4-7. 
Uluslararası İlişkiler Disiplininde Ontolojik Güvenlik Teorisi:

Kavram ve Literatür Odaklı Bir İnceleme

etkilerine odaklanmaktadır. Kinnvall'un bu kitabı, daha önce yayımladığı "Nationalism, Religion and the Search for Chosen Traumas" makalesindeki tema ile de benzer özellikler taşımaktadır. ${ }^{78}$ Kinnvall, adı geçen makalede küreselleşmeyle birlikte artan belirsizlik içinde, yerinden olmanın yol açtığı dini kimlik yapılanmalarına Sih ve Hindu örnekleri üzerinden bakmaktadır.

Kinnvall'un Linden'la birlikte 2010 yılında yayımladığı makalesinde de yine kimlik inşası üzerinden ontolojik güvenlik okuması yapılmakta; 21. yüzyılda küreselleşme, artan göç, yoğunlaşan korku ortamı ve terör iklimiyle birlikte, belli bir gruba/ideolojiye/inanca olan aidiyetlerin "biz" ve "öteki" ayrımlarını çoğalttığını öne sürülmektedir. ${ }^{79}$ Çalışmada bir yandan küreselleşmenin göç ve çok kültürlülük üzerindeki güvenlik/güvensizlik yansımaları tasvir edilirken, diğer yandan, yine küreselleşmenin bir diğer etkisi olan bireylerin normalden fazla sayıda insanla ilişki kurmasını gerektiren "diyalog" kavramı üzerinde durulmaktadır. Küreselleşme, kimlik ve ontolojik güvenlik ilişkisi üzerinden yürütttüğü analizleri 2017 yılında yazdığı bir başka makaleyle devam ettiren Kinnvall, Ted Svensson'la yaptığı bu çalışmada bu kez "cemaat kimliklerine" odaklanmaktadır. ${ }^{80}$ Çalışmada ulusötesi bir boyutta, aleni olarak faaliyet gösteren Tebliğ Cemaati hakkında var olan algilar incelenmekte; bu vaka üzerinden küresel yönetim ve ulusötesi yaklaşımın ulusal güvenlikteki yerleri tartışılmaktadır. Makalede ayrıca Dipesh Chakrabarty'nin "madun geçmişler" teorisi ${ }^{81}$

\footnotetext{
${ }^{78}$ Catarina Kinnvall, "Nationalism, Religion and the Search for Chosen Traumas", Ethnicities, 2002, Cilt: 2, No: 1, 79-106, s. 79.

${ }^{79}$ Catarina Kinnvall ve Jitka Lindén, "Dialogical Selves between Security and Insecurity Migration, Multiculturalism, and the Challenge of the Global", Theory \& Psychology, 2010, Cilt: 20, No: 5, 595-619, ss. 595-596.

${ }^{80}$ Catarina Kinnvall ve Ted Svensson, "Ontological Security and the Limits to a Common World: Subaltern Pasts and the Inner-worldliness of the Tablighi Jama'at", Postcolonial Studies, 2017, Cilt: 20, No: 3, 333-352, s. 333.

${ }^{81}$ Dipesh Chakrabarty'nin baskın grubun kimlik politikalarıyla dezavantajlı hale getirilen madun toplulukların tarih yazımı üzerine görüşleri için bkz. Dipesh Chakrabarty, Provincializing Europe: Postcolonial Thought and Historical Difference, Princeton
}

\section{1}

Güvenlik Stratejileri

Cilt: 17

Say1: 37 
62

Güvenlik Stratejileri

Cilt: 17

Sayı: 37 öznelliğin güvenliği bağlamında geliştirilmekte ve OGT literatürüne entegre edilmektedir.

Kinnvall toplumsal cinsiyet analizi yaptığ "Feeling Ontologically (In)secure: States, Traumas and the Governing of Gendered Space" çalışmasında ise kimliklerin sosyo-psikolojik köklerini incelemektedir. Hindistan özelinde "ontolojik güven(siz)liğin inşa edilmesinde var olan sosyo-psikolojik koşullar içinde yorumlanan kimlik dinamiklerine" 82 atıfta bulunan yazar, ontolojik güvenlik arayışı içinde, travma ve kolektif hafıza anlatılarının yeniden inşa sürecinde, ülkelerdeki toplumsal cinsiyet alanlarının birebir etkili olduğunu iddia etmektedir. Makalede bir yandan travma ve kriz dönemlerinde ontolojik güvenliğin inşa ediliş şekli ile "ben ve öteki" ayrımlarının, günlük anlatılarla nasıl dönüştürüldügü konularına eğilirken; diğer yandan "ontolojik güvenlik" meselesine "toplumsal cinsiyet" perspektifinden bakmaktadır.

Postkolonyalizmle birleşen bir OGT çalışması olarak ise Kinnvall'un John Cash ile birlikte 2017'de çıkan çalışması örnek verilebilir. Bu çalışmada modernite ve küreselleşmenin tüm zamanlardaki kolonyal/postkolonyal unsurlar üzerine etkileri ile kimlik ve kültür bağlamında, topluluklarda ve devletlerde ortaya çıkan ontolojik güvensizliklere odaklanılmaktadır. ${ }^{83}$ Yazarlara göre, küresel serbest ticaret ve sermaye akımları ile iletişim, bilgi, seyahat teknolojilerinin getirdiği krizler ve politik belirsizlikler yeni ontolojik güvensizliklerin doğuşuna kaynaklık etmekte, bu da farklı yollarla da olsa, istikrar arayışlarına yol açmaktadır.

Günümüzdeki çalışmalarda sıklıkla kullanılan popülizm sorunsalı, gerçek-sonrası (post-truth) gibi kavramlar da ontolojik güvenlik literatüründe işlenmektedir. Örneğin Kinnvall, Avrupa'da yükselen aşırı sağ hareketler ve popülizmin dışlayıcı söylemlerinde kullanılan

University Press, Princeton, 2000, 97-113.

${ }^{82}$ Catarina Kinnvall, "Feeling Ontologically (In)secure...", s. 52.

${ }^{83}$ Catarina Kinnvall ve John Cash, "Postcolonial Bordering and Ontological Insecurities", Postcolonial Studies, 2017, Cilt: 20, No: 3, 267-274, ss. 267-270. 
Uluslararası İlişkiler Disiplininde Ontolojik Güvenlik Teorisi:

Kavram ve Literatür Odaklı Bir İnceleme

ontolojik tehditlerle, Avrupa'da eşzamanlı olarak yükselen biyolojik ve kültürel 1rkçılık hareketleri arasındaki psikolojik ilişkiyi ortaya koyabilmek amaciyla, "Racism and the Role of Imaginary Others in Europe" eserini yayımlamıştır. ${ }^{84} \mathrm{Bu}$ araştırmada bir anket çalışmasına da yer veren Kinnvall, Avrupa'da yaşanan ekonomik kriz, göçmenler ve Brexit krizi kargaşasında yerleşik halkta yükselen kaygının, bununla birlikte politikacılar tarafindan kullanılan korku politikalarının ontolojik güvensizliğe ve bunun neticesinde zenofobi ve irkçılığa yol açtığını sosyo-psikolojik gerekçelerle kanıtlama çabasındadır. 2018 yılında yayımladığı bir diğer makalesinde ise Kinnvall, popülist siyasetin postkolonyal imgeleriyle; belirsizlik, korku ve endişeyi tetikleyen anlatı ve söylemler arasındaki bağı incelemektedir. ${ }^{85}$ Son günlerde etkisi giderek artan "gerçek-sonrası" tartışmaları ve bu çerçevede üretilen "alternatif" olguların; devlet söylem ve anlatıları üzerindeki etkisine değinen Kinnvall, bu sayede söz konusu söylem ve anlatıların duygusal cazibelerinin nasıl artırıldığını, popülist siyaset analizleri eşliğinde ortaya koymaktadır.

Kinnvall Hindistan siyasetine dair 2019 Mayıs'inda yayımlanan makalesinde de yine popülizm odaklı bir analiz yapmıştır. Yazar bu makalede Hindistan Başbakanı Narendra Modi'nin milliyetçilik, inanç, Hindu maskülinitesi ve nativizm ${ }^{86}$ üzerine popülist anlatılarını kullanarak Hindistan'daki ontolojik güvensizlik durumunu eleştirel bir perspektiften açıklama çabasındadır. ${ }^{87}$ Bunu yaparken yazar, Hindistan'da

${ }^{84}$ Catarina Kinnvall, "Racism and the Role of Imaginary Others in Europe", Nature Human Behaviour, 2017, Cilt: 1, No: 0122, 1-4, ss. 1-2.

${ }^{85}$ Catarina Kinnvall, "Ontological Insecurities and Postcolonial Imaginaries: The Emotional Appeal of Populism”, Humanity \& Society, 2018, Cilt: 42, No: 4, 523-543, s. 523.

${ }^{86}$ Nativizm (nativism) ya da "doğuştanc1lık" bir ülkede doğan/yerleşik insanların, başka bir yerden bu ülkeye gelen insanlardan daha önemli olduğu düşüncesidir. Aşırı sağ literatürde yer bulan bu ideolojiye göre, yerli olmayan unsurlar aslında ulus-devleti tehdit etmektedir. Bkz. Catarina Kinnvall, "Fear, Insecurity and the (Re)Emergence of the Far Right in Europe", Paul Nesbitt-Larking, Catarina Kinnvall, Tereza Capelos ve Henk Dekker (eds.), The Palgrave Handbook of Global Political Psychology, Palgrave Macmillan, England, 2014, 316-335, s.323.

${ }^{87}$ Catarina Kinnvall, "Populism, Ontological Insecurity and Hindutva: Modi and the Masculinization of Indian Politics, Cambridge Review of International Affairs, 2019, 
64

Güvenlik Stratejileri

Cilt: 17

Sayı: 37

hayali bir ontolojik güvenlik limanı arayanlar için, Modi'nin, Lacancı bir anlayışla, popülist anlatıları, sembolleri, kolektif hafızayı ve mekânları nasıl araçsallaştırdığını gözler önüne sermektedir. Çalışmada "şizofrenik milliyetçilik" olarak tanımlanan Hindu köktenciliği Hindutva'ya ait popülist söylemlerle, azınlıkların nasıl ötekileştirildiği ve saldırıya uğradığı ontolojik güvensizlik olgusu üzerinden, ilgi çekici bir biçimde açıklanmaktadır. $^{88}$

OGT literatüründe Kinnvall'la eş-zamanlı olarak çalışmalar yapan Jennifer Mitzen'in eserleri incelendiğinde ise, bunların önemli bir kısmının $\mathrm{AB}$ odaklı olduğu görülmektedir. 2004 yılında yayımladı̆̆ 1 bir çalıştay raporunda Mitzen, dünya siyasetindeki ontolojik güvenlik tartışmalarından yola çıkarak, AB'nin; geliştirmeye çalıştığ 1 Ortak Dışişleri ve Güvenlik Politikası'yla kurumsal kimliğini tehlikeye atıp atmayacağını tartışmaktadır. ${ }^{89} \mathrm{Bu}$ amaçla Mitzen, demokrasi ve kapitalizmi benzer şekilde uygulayan ABD ile AB'yi kıyaslamakta; ABD'nin askerî gücünün ahlaki kimliğiyle ve misyonuyla ilintili olan bir medeniyet aracı olarak görüldüğünden bahsetmektedir. Ancak Mitzen ABD'nin tersine, AB'nin askerî güç yeteneğine sahip olsa bile, "sivil" (civilian) ve "medenileştirici" (civilizing) kimliğinin değişmeyeceğini iddia etmekte ve bunun sebebini devletlerarası rutinlere dayandırmaktadır. Böylelikle ontolojik güvenliğin temel unsuru olan rutinleri, devletlerarası düzeye taşıyan Mitzen'e göre ontolojik güvenlik anlamında istikrarı sağlayan $\mathrm{AB}$ rutinleri ve bu rutinlerle oluşan $\mathrm{AB}$ kimliği, değişime direnç gösterecektir. Dolayısıyla askerî yetenekler kazansa bile, $\mathrm{AB}$ mevcut "sivil" ve "medenileştirici" kimliğini koruyacaktır. Mitzen, bu raporun devamı niteliğinde olan, 2006 yılında yayımladığı bir

$1-20$, ss. $1-2$.

${ }^{88}$ A.g.m., s. 11.

${ }^{89}$ Mitzen, "Ontological Security in World Politics, and Implications...", ss.1-2.

${ }^{90} \mathrm{AB}$; demokrasi, hukukun üstünlüğü, insan hakları ve diplomatik yolları öncelemesi nedeniyle "normatif", "sivil", "barışçıl" veya "medenileştirici" gibi olumlu sıfatlarla tanımlanmaktadır. 
Uluslararası İlişkiler Disiplininde Ontolojik Güvenlik Teorisi:

Kavram ve Literatür Odaklı Bir İnceleme

makalesinde de ontolojik güvenlik temelinde $\mathrm{AB}$ rutinlerini ortaya koymakta ve $\mathrm{AB}$ kimliğinin değişime direneceğine vurgu yapmaktadır. ${ }^{91}$

Mitzen'in 2018 yılında yayımlanan bir başka çalışmasında da AB'nin çokça eleştiri alan göç politikalarının sebeplerine, Avrupa'da ortaya çıkan ontolojik güvenlik kaygıları, korkular, rutinler ve savunma pratikleri açısından bakmaktadır. ${ }^{92}$ Her ne kadar AB, genelde egemen devlet faraziyesini belirsizleştiren, ulus-ötesi bir politik proje olarak görüyor olsa da artan göç sorununa verdiği tepkiler, birliği "Neo-Vestfalyan" olmakla itham etmektedir. Bunun sebebi AB göç politikasının; iltica, asimilasyon ve insan haklarına yönelik anlaşmalar eşliğinde sınır korumaya öncelik vermesidir. Yazar bu durumu, yine bireyden devlet düzeyine geçiş yaparak, "ev-vatan" benzetmesi ile açıklar. Buna göre, AB'nin sınırlandırıcı göç politikaları; ontolojik güvenlik hissi, tehditten uzaklık, aidiyet, öznellik ve kimlik konuları eşliğinde "misafirleri" "ev"ine (vatan) kabul etmeme metaforuyla açılanabilir. Mitzen sınırları ayrıcalıklı kılan bu monolojik "ev" söylemi yerine, çoğul bir yapı önermektedir.

Mitzen, aynı sene yayımladığı "Anxious Community: EU as (In)security Community" çalışmasında da AB'yi "kaygılı topluluk" olarak nitelendirmekte ve göç krizi, Euro krizi, Brexit, popülizm ve aşırı sağın yükselişiyle artan bu kaygıların yol açabileceği değişime dikkat çekerek, Rumelili'ye atıfta bulunmaktadır. ${ }^{93} \mathrm{Bu}$ çalışmanın önceki bölümlerinde de değinildiği üzere, Rumelili’nin, kaygının değiştirici bir gücü olduğu ve seçim özgürlüğü tanıdığı tezinden hareketle,

\footnotetext{
${ }^{91}$ Jennifer Mitzen, “Anchoring Europe's Civilizing Identity: Habits, Capabilities and Ontological Security", Journal of European Public Policy, 2006, Cilt: 13, No:2, 270285, ss. 270-272.

${ }^{92}$ Jennifer Mitzen, "Feeling at Home in Europe: Migration, Ontological Security, and the Political Psychology of EU Bordering", Political Psychology, 2018, Cilt: 39, No: 6, 1373-1386, ss. 1373-1375.

93 Jennifer Mitzen, "Anxious Community: EU as (In)security Community", European Security, 2018, Cilt: 27, No: 3, 393-413, ss. 393-395. Kaygının değiștirici, seçim özgürlüğü sağlama gücü için bkz. Rumelili, "Ontological (In)security and Peace Anxieties...", s. 13.
}

\section{5}

Güvenlik Stratejileri

Cilt: 17

Say1: 37 
66

Güvenlik Stratejileri

Cilt: 17

Sayı: 37

Mitzen, bu kaygilı topluluğun (AB'nin) olumlu yönde değişime uğrama ihtimalinden bahsetmektedir. Yazar, AB'de göç yönetişimi bağlamında, göçün güvenlik-dışılaştırılmasının (desecuritization) zorluğuna değinirken, $\mathrm{AB}$ değerleri ve kurumları üzerinden, göç yönetişiminde sorun yaratan mekanizmaları ortaya çıkarmayı önermektedir.

Bir başka analizinde ise Mitzen; Manners ve Kinnvall ile birlikte, AB'nin varoluşuyla ve güvenliğiyle ilgili yaşanan krizlerin, hayatlarını fiziksel olarak tehdit etmiyor olsa dahi, Avrupalı sıradan insanlarda kaygıya neden olduğunu; dolayısıyla onları ontolojik güvensizliğe sürüklediğini iddia etmektedir. ${ }^{94}$ Makaleye göre $\mathrm{AB}$ 'yi fiziksel güvenlikten daha çok etkileyen ve mülteciler, ekonomik kriz, aşırı sağın yükselişi, Brexit ya da terörizm gibi sorunların arkasına saklanmakta olan asıl şey, gerçekte örgütün artan ekonomik ve sosyal beklentileri karşılayamayacağı kaygısına, dolayısıyla da ontolojik güvensizliğe sahip olmasıdır. Çalışmada, ontolojik güvenliğin, $A B$ 'de yaşanan siyasi hareketleri, toplumsal kaygı ve korkuları açıklayan anahtar bir kavram olduğu iddia edilmektedir. ${ }^{95}$

Jennifer Mitzen'in güvenlik ikilemine uyguladığı ontolojik güvenlik açılımıyla ve uzun süreli çatışmalara getirdiği farklı yorumlarla ontolojik güvenlik çalışanlara ilham kaynağı olan ve OGT literatüründe

${ }^{94}$ Catarina Kinnvall, Ian Manners ve Jennifer Mitzen, "Introduction to 2018 Special Issue of European Security: Ontological (in)Security in the European Union", European Security, 2018, Cilt: 27, No: 3, 249-265, ss. 249-250.

${ }^{95}$ Mitzen, 2016 tarihli bir başka eserinde ise, nükleer İran'la olması muhtemel bir savaştan bahsedilirken kullanılan "akla gelmez - imkânsız savaş" (unthinkable war), terimine bakarak, yine bir ontolojik güvenlik analizi yapmıştır. Bkz. Jennifer Mitzen, "Security Communities and the Unthinkabilities of War", The Annual Review of Political Science, 2016, Cilt: 19, 229-248, ss. 229-231. Mitzen'in Larson'la birlikte 2017 yılında yayımladıkları "Ontological Security and Foreign Policy" ismini taşıyan makale de benzer şekilde, ontolojik güvenlik perspektifiyle dış politikayı yorumlayan çalışmaların değerlendirilmesini içermektedir. Makalede yazarlar, dış politikanın geleneksel öznesini oluşturan devletleri, "ontolojik güvenlik arayışında olan vatandaşlarının ihtiyaçlarına dış politika tercihleriyle cevap veren devletler" ile "fiziksel güvenliğin yanı sıra, ontolojik güvenlik arayışında olan devletler" şeklinde ikiye ayırmaktadır. Bkz. Jennifer Mitzen ve Kyle Larson, "Ontological Security and Foreign Policy”, Oxford Research Encyclopedia of Politics, 2017, 1-26, ss.1-3. 
Uluslararası İlişkiler Disiplininde Ontolojik Güvenlik Teorisi:

Kavram ve Literatür Odaklı Bir İnceleme

popülerliğini sağlayan bir diğer eseri ise, İsrail-Filistin sorununa dair tespitler içeren "Ontological Security in World Politics: State Identity and the Security Dilemma" makalesidir. ${ }^{96}$ Yazarın 2006' da yayımladığı bu makale, irrasyonel devlet davranışları ve uzun süreli çatışmaları ontolojik güvenlik perspektifinden açıklamaya çalışmaktadır. ${ }^{97}$ Mitzen, Soğuk Savaş sonrası güvenlik ikilemi tartışmalarında yer alan, devletlerin güvenlik arayışı içindeyken iyi niyetle davrandıkları varsayımını sorgulamakta; ontolojik güvenlik ihtiyacı nedeniyle, devletlerin gerçekte mevcut güvenlik ikilemlerinden çıkmaya istekli olmadıklarını ve güç rekabetine devam ettiklerini ileri sürmektedir. $\mathrm{Bu}$ bakış açısıyla İsrail ve Filistin aslında, ontolojik anlamda güvende kalmak için, aralarındaki sorunu çözmeyi istememekte; bunun için gerekirse fiziksel anlamdaki güvenliklerinden de vazgeçmektedirler. ${ }^{98}$

İlk bakışta ironik gibi görünse de Mitzen'e göre devletler risk yaratıyor olsalar dahi tehlikeli rutinlere bağlanabilirler. Güvenlik çalışmalarında devletlerin fiziksel güvenlik arayışlarına fazlaca yer verilip, ontolojik güvenliğin ihmal edildiğini düşünen Mitzen, "güvenlik ikilemi” "nin "çatışmalara bağlanmak" gibi rasyonel olmayan devlet davranışlarını açıklayamadığını öne sürmektedir. Oysa Mitzen için, "benliğin güvenliğini" sağladığ i için çatışmalardan, dolayısıyla da kurucu kimliğin yeniden üretilmesine imkân veren tehlikeli rutinlerden vazgeçmek ontolojik güvensizliğe yol açmakta; bu nedenle de taraflar görünenin aksine aslında bu rutinlerden vazgeçmek istememektedir. Mitzen'e göre, realist ekolün bir "güvenlik ikilemi" olarak tanımladığı İsrail-Filistin sorununda, iki taraf da kendisini "güvenlik arayıcısı" ya da "koşullara bağlı saldırgan" devlet olarak tanımlamaktadır. Oysa hiçbir strateji söz konusu aktörleri eylem ve kimliklerini uzlaştırmaya, var olan rutinlerini ve anlatılarını değiştirmeye zorlamadığı için, tarafların bir araya gelmelerinin ve karşılıklı güven duymalarının

\footnotetext{
${ }^{96}$ Jennifer Mitzen, “Ontological Security in World Politics...”, s. 354.

${ }^{97}$ Rumelili, "Uluslararası İlişkilerde Kimlik ve Ontolojik Güvenlik", Bilim ve Sanat Vakfi, Bülten, Cilt: 83, İstanbul, 9 Ekim 2013, 8-10, s. 9.

${ }^{98}$ Mitzen, "Ontological Security in World Politics...", ss.361-363.
}

Güvenlik Stratejileri

Cilt: 17

Say1: 37 
68

Güvenlik Stratejileri

Cilt: 17

Sayı: 37

mümkün olmadığını belirtmektedir. Bu durum da çatışmayı çözümsüz hale getirmekte ve rutinleşen ihtilaf ilişkisi kalıcı olmaktadır. ${ }^{99}$

$\mathrm{Bu}$ bölümde yer verilecek bir diğer önemli isim olan Steele ise OGT literatürüne 2005 yılında yayımladığ1 "Ontological Security and the Power of Self-Identity: British Neutrality and the American Civil War" adlı eseriyle giriş yapmıştır. Yazar bu eserinde Amerikan İç Savaşı'nda Büyük Britanya'nın tarafsız kalma kararının arkasındaki ontolojik kökenleri, söylem bazında incelemektedir. ${ }^{100}$ Abraham Lincoln'ün Özgürlük Bildirgesi'nin İngiltere'de var olan müdahaleci tartışmalar üzerindeki etkisini inceleyen yazar, bu bildirgenin İngilizler için nasıl bir anlam farklılaşması yarattığını kimlik ve ontolojik güvenlik kavramları üzerinden irdelemekte ve bir olaydan toplumların ontolojik güvenlikleri etkilendiğinde, bunun en az fiziksel güvenliklerine etki kadar önemli olabileceğini öne sürmektedir.

Nitekim Steele, "Ontological Security in International Relations: Self-Identity and the IR State" ismini taşıyan kitabında ise "devletler uluslararası arenada hayatta kalmayı mı, yoksa bundan daha fazlasını $\mathrm{m} 1$ ister?" sorusundan yola çıkarak bir ontolojik güvenlik analizi daha yapmaktadır. ${ }^{101}$ Yazara göre devletlerin; genelde realist, özelde de rasyonel seçim akımını takip edenlerin iddia ettiğinin aksine, sadece maddi birtakım çıkarlar için değil, ahlaki, insani ya da onur/şeref gibi sebeplerle de çatışmaya girebildiğini düşünmek gerekir, çünkü bu tür sebepler bireyde olduğu gibi, toplum ya da devletlerde de “öz"ün bütünlügünü korumakla ilgili kaygıların yansımasıdır ve bu durum ontolojik güvenlikle yakından ilgilidir. ${ }^{102}$ Çalışma kapsamında, ABD’nin

\footnotetext{
${ }^{99}$ A.g.m., ss. 353-354.
}

100 Brent J. Steele, "Ontological Security and the Power of Self-Identity: British Neutrality and the American Civil War", Review of International Studies, 2005, Cilt: 31, No: 3, 519-540, ss. 519-520.

${ }^{101}$ Brent J. Steele, Ontological Security in International Relations: Self-Identity and the IR State, Routledge, New York, 2008, ss. 1-2.

${ }^{102}$ Ertem, Geleneksel Amerikan Kimlik ve Güvenlik Algısının..., s.72. Bu bakış açısı, öncüsü sayıldığı Realizm ekolü açısından şaşırtıcı olsa da Thucydides'in, savaşın 3 temel sebebinden birinin "onur" olduğu iddiası ile uyum içindedir. (Thucydides'in öne sürdüğü 
Uluslararası İlişkiler Disiplininde Ontolojik Güvenlik Teorisi:

Kavram ve Literatür Odaklı Bir İnceleme

yakın tarihli müdahalelerinden de bahseden Steele'ye göre, ABD 11 Eylül'den sonra yaptığı askerî operasyonlarla, bir yandan kendi vatandaşlarının fiziksel güvenliklerini garantiye alırken, diğer yandan ötekilere zarar verebilecek her türlü politikasını meşrulaştırmaktadır. $\mathrm{Bu}$ ise aslında değer bazlı, geleneksel Amerikan kimliği ile çelişmektedir. Yazar, ABD'nin çıkarlarını; ahlaki mecburiyetlerinden ve uluslararası arenadaki liberal, demokrat kimliğinden önde tutuyor olmasının Amerikan toplumunda kaygı yarattığını ve bu kaygının da ontolojik güvensizliğe neden olduğunu iddia etmektedir.

Amerikan askerlerinin Irak ve Afganistan'a yollanmasının ve savaş bölgelerindeki hapishanelerde tutuklulara yaptıkları işkencelerin altında yatan nedenleri, Amerikan kimliği, onur algısı ve ontolojik güvenlik bağlamında analiz ettiği 2008 y1lına ait makalesinde ${ }^{103}$ ise Steele, Foucault'nun "kendilikle" ilgili olduğunu düşündüğü, "evrensel olmayan etik" 104 anlayışından faydalanmaktadır. Yazara göre, ABD askerleri, liberal nitelikli ulusal ideallerini terörizmle savaşmak ve güvenliği sağlamak için terk etmekte ve bu fedakârlığ yine Amerikan kimliğinin bir unsuru olan "ulus onurunu korumak adına" yapmaktadır. Irak ve Afganistan'daki hapishanelerde işkenceleri gerçekleştiren askerlerin psikolojisi bozuk insanlardan oluştuğu iddialarının gerçeği yansıtmadığını öne süren Steele'ye göre ABD'li askerler, işkence ettikleri insanların kimliklerine, yani ontolojik güvenliklerine zarar veren işkence türlerini bilerek seçmiş; bu sayede "öteki” olarak gördükleri üzerinden, kendi ontolojik güvenliklerini sağlamlaştırmak istemişlerdir.

diğer iki sebep ise korku ve çıkardır.) Bkz. Thucydides: The War of the Peloponnesians and the Athenians, (Der. ve Çev. Jeremy Mynott), Cambridge University Press, Cambridge, 2013, s.46.

${ }^{103}$ Brent J. Steele, “ 'Ideals That Were Really Never in Our Possession': Torture, Honor and US Identity", International Relations, 2008, Cilt: 22, No: 2, 243-261, ss. 243-244.

104 Ayrıntılar için bkz. Michel Foucault, Discipline and Punish: The Birth of the Prison, Vintage Books, New York, 1977 ve M. Foucault, On the Genealogy of Ethics: An Overview of Work in Progress, Pantheon, New York, 1984.

Güvenlik Stratejileri

Cilt: 17

Say1: 37 
2019 Şubat'ında yayımladığı makalesinde de Steele, 2000-2010

Güvenlik Stratejileri

Cilt: 17

Sayı: 37 yıllarında Irak ve Afganistan'dan vatanlarına dönen Amerikan askerlerinin sosyal medyada paylaşılan, aileleriyle kavuşma videolarını ontolojik güvenlik perspektifinden incelemektedir. ${ }^{105} \mathrm{Bu}$ videolarda, güven veren kamuya açık alanlarda, aile üyelerine sürpriz yaparak ülkesine/evine dönen Amerikan askeri teması işlenmiştir. Yazara göre, yeniden bir araya gelişlerin kamusal alanlarda gerçekleşmesi ve bunun filme alınması, bir yandan geçmişle bağlantıyı sağlarken, diğer yandan da toplumsal hafizaya ait birtakım ritüellerle topluma güven duygusu aşılamayı amaçlamaktadır. Ayrıca bu videolarda, askerlerin savaşa neden gittiğinin sorgulanmasını engelleme arzusu vardır ve sıradan günlük rutinlere geri dönüşlerle, kaosun "geçici"liği vurgulanmak istenmektedir. Steele, Amerikan yaşamının günlük rutinlerine dair ipuçları taşıyan ve adeta "savaş bitti; artık güvendeyiz" mesajı vermeye çalışan bu videoların; bir yandan ontolojik güvenliği sağlama amacı güderken, diğer yandan popülizmi araçsallaştırdığını ve bunun da aslında yaşadığımız kaos ve endişe çağında sıkça rastlanan ontolojik güvenlik arayışının bir diğer kanıtı olduğu iddiasındadır.

Steele, Donnelly ile birlikte 2019 yılında yayımladığı çalışmada ise savaş gibi olumsuz tarihi tecrübelerin ardından üretilen "anlatıların", aslında tarihi çarpıtmak veya unutturmak gibi bir etkisi olduğu ve bu tip tarih anlatılarına da, tıpk1 ontolojik güvenlik ve güvenlikleştirme konularında olduğu gibi eleştirel bakılması gerektiği tezi işlenmektedir. ${ }^{106}$ "Ontological Insecurities and the Politics of Contemporary Populism" başlıklı makalede ise Steele'nin, Homolar'la birlikte ontolojik güvenliğin daha ziyade kavramsal boyutuyla ilgilendiği görülmektedir. ${ }^{107} \mathrm{Bu}$ çalışmada güvensizlikle arasındaki

${ }^{105}$ Brent J. Steele, "Welcome Home! Routines, Ontological Insecurity and the Politics of US Military Reunion Videos", Cambridge Review of International Affairs, 2019, 1-22, ss. 1-3.

${ }^{106}$ Brent J. Steele ve Faye Donnelly, "Critical Security History: (De)securitisation, Ontological Security, and Insecure Memories", European Journal of International Security, 2019, No: 4, 209-226, ss. 209-212.

${ }^{107}$ Brent J. Steele ve Alexandra Homolar, "Ontological Insecurities and the Politics of 
Uluslararası İlişkiler Disiplininde Ontolojik Güvenlik Teorisi:

Kavram ve Literatür Odaklı Bir İnceleme

ilişkiyi çözümleyerek bir popülizm eleştirisi sunan yazarlar, ontolojik güvenliğin temel unsurları olan rutinler ve kaygı, krizler ve güvensizlik ortamı, anlatılar ve toplumsal hafiza kavramları üzerinde de durmaktadır. Benzer şekilde 2014'te Innes'le birlikte yazdığı bir kitap bölümünde de Steele, travma ve hafiza konularılya ontolojik güvenliği birleştirerek, devletlerin kendi varlıklarını; kolektif hafiza ve travmatik deneyimleri kullanarak nasıl ontolojik anlamda güvenli hale getirdiklerini göstermeye çalışmıştır. Çalışmada incelenen örnek olay ise Arap Baharı'yla birlikte Mısır'da atlatılmaya çalışılan "ontolojik güvensizlik durumu" ve "yeni düzen inşasıdır." çalışmasında ise; Orta Doğu'da yaşanılan savaşlar, göç sorunu, ekonomik kriz, ABD'de Trump'un başkan seçilmesi, Avrupa'da aşırı sağın ve popülizmin yükselişiyle birlikte, aslında küresel bir kriz yaşandığını ve bu krizin Amerika'nın siyasal yapısında yarattığı kaygı ile, geleneksel Amerikan kimliğinde bir değişim meydana geldiğini öne sürmektedir. ${ }^{109}$

Steele'nin UI'de OGT'ye feminist teoriyi entegre eden çalışmaları da vardır. 2009'da Delehanty ile birlikte yayımladıkları "Engaging the Narrative in Ontological (In)security Theory: Insights from Feminist IR" makalesinde Steele ontolojik güvenlik çalışmalarında devletlerin özkimlik anlatılarında "cinsiyetli" ve "cinsiyetçi" olduklarını iddia etmektedir. $\mathrm{Bu}$ bakış açısıyla yazarlar, baskın devlet öz-kimlik anlatılarının eril karakterine dikkat çekmekte; içsel otobiyografik anlatının feminenliğine vurgu yapmaktadırlar. Yazarlara göre bu durum, devletlerin "cinsiyetçi" varsayımlarla öz-benlik algılarına tutarlılık ve birlik sağlamayı amaçladıklarını göstermektedir. ${ }^{110}$ Steele 2017 yılında

Contemporary Populism", Cambridge Review of International Affairs, 2019, 1-8, ss. 1-3.

${ }^{108}$ Brent J. Steele ve Alexandria J. Innes "Memory, Trauma and Ontological Security", Erica Resende ve Dovile Budryte, (eds.), Memory and Trauma in International Relations: Theories, Cases and Debates, Routledge, New York, 2014, 15-29, s. 15.

${ }^{109}$ Brent J. Steele ve Jelena Subotic, "Moral Injury in International Relations", Journal of Global Security Studies, 2018, Cilt: 3, No: 4, 387-401, ss. 387-388.

${ }^{110}$ Brent J. Steele ve Will K. Delehanty, "Engaging the Narrative in Ontological (in)Security Theory: Insights from Feminist IR", Cambridge Review of International Affairs, 2009, Cilt: 22, No: 3, 523-540, ss. 523-525. 
72

Güvenlik Stratejileri

Cilt: 17

Sayı: 37

yazdığı makalede ise, CIA örgütü özelinde yapılan işkencelerin ontolojik güvenlik okumasını, Laura Sjoberg'in toplumsal cinsiyet argümanı; CIA rutinleri ve kamuoyu ile politik seçkin söylemleri arasındaki etkileşim üzerinden yapmakta ve bu sayede söz konusu işkencelerin yeniden benimsenmesinin altında yatan olguları araştırmaktadır. ${ }^{111}$

Tüm bu çalışmalara ilaveten, söz konusu yazarların Uİ alanında OGT'yi açıklayan bazı ortak çalışmaları da mevcuttur. Bunlara örnek olarak Mitzen'in Kinnvall'la birlikte 2017 'de ve 2018'de yazdıklarr; dünya siyasetini ve küreselleşme ile artan kaygıların yarattığı güvensizlik ortamını ontolojik güvenlik açısından analiz ettikleri makaleler verilebilir. ${ }^{112} \mathrm{Bu}$ özel sayıda yer alan makaleler, çatışma ve toplum, ülke ve birey olmak üzere, analiz düzeyleri ve odakları farklılaşan; devletlerin ontolojik güvenlik arayışlarını ya da ontolojik güvensizliklerini alternatif Uİ teorilerini baz alarak açıklayan çalışmalardan oluşmaktadır. Görüldüğü üzere; küreselleşme, ötekileştirme, azınlık problemleri, popülizm, toplumsal travma, ırkçılık, aşırı sağ, göç, çok kültürlülük, kolektif hafıza, inanç, milliyetçilik, aidiyet, kimlik inşası gibi konuların yanı sıra, ölümlü uluslar, devlet anlatılarındaki manipülasyonlar, güvenlikleştirme süreçleri, mağduriyet, utanç, suçluluk, anlamsızlık kaygısı gibi birbirinden farklı hususlarda, dünyanın pek çok bölgesinden örnek olaylar incelenerek, ontolojik güvenlik odaklı çalışmalar yapılmaktadır. Bu durum, OGT'nin zengin içerikli ve interdisipliner yapısını gözler önüne sermektedir. ${ }^{113}$

\subsection{Ui'de OGT'ye Türkiye'den Katkılar}

Türkiye'de Uİ alanında yapılan ontolojik güvenlik çalışmaları Batı'ya kıyasla oldukça azdır. Bununla birlikte 2010 sonrası Türkiye'de

\footnotetext{
${ }^{111}$ Brent J. Steele, "Organizational Processes and Ontological (In)security: Torture, the CIA and the United States", Cooperation and Conflict, 2017, Cilt: 52, No: 1, 69-89, ss. 69-71.

${ }^{112}$ Bkz. Catarina Kinnvall ve Jennifer Mitzen, "An Introduction to the..." ve Catarina Kinnvall ve Jennifer Mitzen, "Ontological Security and Conflict: The Dynamics of Crisis and the Constitution of Community", Journal of International Relations and Development, 2018, Cilt: 21, No: 4, 825-835.

${ }^{113}$ Bkz. Ejdus, Crisis and Ontological...
} 
Uluslararası İlişkiler Disiplininde Ontolojik Güvenlik Teorisi:

Kavram ve Literatür Odaklı Bir İnceleme

konu ile ilgili çalışmaların arttığını ve bu çalışmalarda özellikle Bahar Rumelili'nin önemli bir yeri olduğunu vurgulamak gerekir. Yazarın, aralarında 2015 tarihli Conflict Resolution and Ontological Security adlı derleme kitabının da olduğu, ontolojik güvenlik teorisini temel alan çok sayıda çalışması mevcuttur. ${ }^{114}$

Bunun dışında, Pınar Bilgin ve Başak İnce'nin, Rumelili'nin yukarıda adı geçen kitabında, yazdıkları bölüme ${ }^{115}$ ilaveten, "Security and Citizenship in the Global South: In/securing Citizens in Early Republican Turkey (1923-1946)"116 adlı bir ontolojik güvenlik çalışmaları olduğunu hatırlatmak gerekir. Pınar Bilgin'in, 2010 tarihli "Identity/Security" ${ }^{117}$ başlıklı çalışması da ontolojik güvenlik yaklaşımına yer vermektedir. Ayrıca Ayşe Betül Çelik'in yine Rumelili'nin kitabında yer alan "The Kurdish Issue and Levels of Ontological Security" başlıklı bölümü de Türkiye'de ontolojik güvenlik perspektifiyle yapılan çalışmalara örnektir. ${ }^{118}$

114 Detaylar için bkz. Rumelili, "Identity and Desecuritisation...”; Bahar Rumelili, "Breaking with Europe's Pasts: Memory, Reconciliation, and Ontological (In)security", European Security, 2018, Cilt: 27, No: 3, 280-295; Bahar Rumelili, "Identity and Desecuritization: Possibilities and Limits", NUPI's Research Seminar Series, 2011, Oslo, February, 1-36; Rumelili ve Karadağ, "Göç ve Güvenlik..."; Rumelili, "Ontological (In)security...", Rumelili (ed.), Conflict Resolution and...; Bahar Rumelili, "Integrating Anxiety into International Relations Theory: Hobbes, Existentialism, and Ontological Security", International Theory, Cilt: 12, No:2, 2020, 257-272. Rumelili son olarak, Umut Can Adısönmez ile birlikte Türkiye'de yapılacak çalışmalara katkı olarak OGT konulu Türkçe bir makale de yayınlamıştır. Rumelili ve Adısönmez, "Uluslararası İlişkilerde Kimlik Güvenlik...”.

${ }^{115}$ Pınar Bilgin ve Başak İnce, “Ontological (In)security of 'Included' Citizens: The Case of Early Republican Turkey (1923-1946)”, Rumelili, (ed.), Conflict Resolution and..., 117-133.

116 Pınar Bilgin ve Başak İnce, "Security and Citizenship in the Global South: In/securing Citizens in Early Republican Turkey (1923-1946)", International Relations, 2015, Cilt: 29, No: 4, 500-520.

${ }^{117}$ P1nar Bilgin, "Identity/Security", J. Peter Burgess, (ed.), The Routledge Handbook of New Security Studies, Routledge, New York, 2010, 81-89.

${ }_{118}$ Ayşe Betül Çelik, "The Kurdish Issue and Levels of Ontological Security", Bahar Rumelili, (ed.), Conflict Resolution and Ontological Security, Routledge, New York, 2015, 52-70. 
74

Güvenlik Stratejileri

Cilt: 17

Sayı: 37

Literatüre, devlet rutinleri ve ulusal kimlik bağlamında Türkiye'den yapılan bir katkı da Aslı Nur Düzgün'ün "Turkish Foreign Policy towards Israel (2008-2019): Routines, Identity and Ontological Security" başliklı İngilizce kitap bölümüdür. ${ }^{19}$ Yazar bu eserinde, Türkiye'nin, ulusal kimliğinin yapı taşları açısından önemli bir yeri olan Filistin'e İsrail tarafından uygulanan politikaları, adeta kendisine karşı yapılmış saydığını ve bu politikalara yüksek sesle itiraz ederek, aslında kendi ontolojik güvenliğini koruduğunu öne sürmektedir. Düzgün'e göre Türkiye, İsrail'e yönelik dış politikası bağlamında ortaya koyduğu eylemlerle aslında Türk halkının ontolojik güvenlik ihtiyacını karşılamaktadır ve bu da Türkiye'yi, Mitzen ve Larson'un, önceki bölümlerde kısaca değinilen, "vatandaşlarının ontolojik güvenlik arayışını dış politika tercihleriyle gidermeye çalışan devletler" kategorisine sokmaktadır.

Son olarak Aslı Ilgit'ın, Deepa Prakash ile kaleme aldığı makale de, Türkiye'nin İsrail'e yönelik dış politikasına diğer ülkelerden gelen eleştirilerin içeride yarattığı duygusal tepkileri ve bu nedenle ortaya çıkan krizleri, yine ontolojik güvenlik bağlamında incelemektedir. Ilgit ve Prakash'a göre, söz konusu eleştiriler Türkiye'de, ontolojik güvenlik teorisi ile uyum içinde, devlet kimliğini sağlamlaştırmak için bir firsat olarak görülmektedir. ${ }^{120}$

\section{Sonuç}

Benliğin (kimliğin/varlığın) zaman ve mekâna uygun şekilde güvenceye alınması anlamına gelen ontolojik güvenlik, fiziksel güvenlikten farklı olarak sosyal yaşamda rutinlerle sağlanan bir süreklilik ve öngörülebilirlik çabasıdır. $\mathrm{Bu}$ rutinler bozulduğunda ise karşılaşılan belirsizlik, kararsızlık ve kaygı, ontolojik güvensizliği açığa çıkarmaktadır. Ontolojik güvensizliği tetikleyen kaygı ise, korkudan

119 Bkz. Aslı Nur Düzgün, "Turkish Foreign Policy towards Israel (2008-2019): Routines, Identity and Ontological Security", Zülfükâr Aytaç Kişman (ed.), Turkey in International Arena: Political and Economic Relations, Editura Universităţii "Aurel Vlaicu", Arad, 2019,13-46, ss.14-15.

${ }^{120}$ Asli Ilgit ve Deepa Prakash, "More than a Feeling: Emotional Responses to International Critism in Erdogan's Turkey", Review of International Studies, 2017, Cilt 43, 130-151. 
farklı olarak, kaynak oluşturacak somut bir nesneye sahip olmayan; neye, kime, niçin hissedildiği anlaşılamayan bir duygudur ve insanı ilk önce hareketsiz bıraksa da değişimin başlangıcını sağlayabilecek, olumlu bir nitelik de taşımaktadır. Rutinler, istikrar, kaygı gibi kavramlar, ontolojik güven(siz)lik kavramının öğeleri olduğundan; bu yaklaşım psikanaliz ve sosyoloji disiplinlerinden Uİ literatürüne bu öğeler eşliğinde aktarılmıştır.

Birey düzeyinde ontolojik güvenlik çalışmalarının Uİye aktarılmasıyla güvenlik literatüründe giderek önem kazanan bu kavram, pek çok teori ve vaka ile birlikte çalışılmıştır. Ontolojik güvenliğin ilgi çeken tarafı, farklı bakış açılarına sahip diğer güvenlik teorileriyle açıklanamayan bazı durumları açıklanabilir hale getirmesidir. $\mathrm{Bu}$ bağlamda ontolojik güvenlik örneğin; devletlerin değişime açık olmadığı varsayılan kimliklerinin/iç-kaynaklı varlıklarının aslında yeniden inşa edilebildiğini, hatta anlatılar aracılığıyla yeniden üretilebildiğini göstermektedir. Ayrıca, zarar görme ihtimaline rağmen, mantığı olmayan ve büyük riskler taşıyan, irrasyonel devlet davranışlarının sebeplerini ve bunların uzun süreli, kronik çatışmalar üzerindeki etkisini açıklayabilmektedir. $\mathrm{Bu}$ yönüyle de ontolojik güvenlik yaklaşımı, güvenlik ve dış politika analizi bağlamında literatüre tamamlayıcı bir nitelik katmaktadır.

Tüm bu özellikleri sayesinde ontolojik güvenlik yaklaşımı, Uİ disiplininde oldukça dikkat çekmiş ve pek çok çalışmaya kaynaklık etmiştir. Ontolojik Güvenlik Teorisi'ne (OGT) dair kavram ve literatür odaklı bir inceleme içeren bu makalede, ontolojik güvenlik yaklaşımında öncül isimler olan Huysmans, McSweeney ve Manners'ın çalışmalarına kısaca yer verilmekle birlikte, ağıllıklı olarak alanda ismi öne çıkan Kinnvall, Mitzen ve Steele'nin OGT konulu eserlerine değinilmiştir. Yapılan inceleme sonucunda; küreselleşme, ötekileştirme, popülizm, toplumsal travma, ırkçılık ve aşırı sağ gibi küresel sorunların yanı sıra; göç, çok kültürlülük, kolektif hafıza, inanç, milliyetçilik, aidiyet ve kimlik inşası gibi konular üzerinde farklı örnek olayları içine alan ontolojik güvenlik çalışmaları yapıldığı görülmüsstür. Bugüne kadar postyapısalcılık, postkolonyalizm, feminizm ve eleştirel güvenlik gibi 
Güvenlik Stratejileri

Cilt: 17

Sayı: 37

pek çok teorik perspektiften faydalanan OGT halen gelişmeye açık bir konumdadır ve çok sayıda farklı çalışmaya öncülük edebilir.

$\mathrm{Bu}$ makale, "ontolojik güvenlik" yaklaşımının, büyük küresel değişimlerin yaşandığı; eşitsizliğin dünya çapında arttığı; aşırı sağın ve dolayısıyla popülizmin yükselişe geçtiği, bölgesel savaşlar ve kitlesel göç hareketleriyle sarsılmakta olan 21. Yüzyıl1, diğer bir deyişle "Kayg1 Çağı" sürmektedir. COVID-19 salgınının da etkisi ile bugün daha çok hissedilen "küresel belirsizlik" hali, felce uğramış "günlük hayat rutinleri" ve artarak devam eden "kaygı" atmosferi içinde yaşanan değişim; psikolojik, sosyolojik ve siyasi bağlamda analiz edilirken de ontolojik güvenlik yaklaşımı kilit bir rol üstlenebilecek kapasitededir. $\mathrm{Bu}$ nedenle de salgın sürecindeki ve sonrasındaki birey, toplum ve devlet reflekslerini anlamlandırmada, ontolojik güvenlik odaklı çok sayıda yeni ve ilgi çekici çalışmanın ortaya çıkması sürpriz olmayacaktır. Ümit edilen, bu incelemenin benzer çalışmaların Türkiye'de de yapılmasına kolaylaştırıcı bir etki yaratmasıdır.

\section{Summary}

This study aims to conceptually and practically assess the ontological security approach, which has long been the subject of numerous academic works in international literature but is not known well enough in Turkey. For Wolfers, security "in an objective sense, measures the absence of threats to acquired values; in a subjective sense, the absence of fear that such values will be attacked". With this strong psychological dimension, security is shaped by perceptions. Ontological security, which can be defined as the security of the "self", not the body, is a basic need both for the societies, the states, and the individuals. Giddens, who used the concept especially while describing the identity and the self of the individual, defined ontological security as "the confidence human

121 Ziya Öniş, "The Age of Anxiety: The Crisis of Liberal Democracy in a PostHegemonic Global Order", The International Spectator, 2017, Cilt: 52, No:3, 18-35, s. 1. 
beings have in the continuity of their self-identity and in the constancy of the surrounding social and material environments of action".

Giddens argues that the individuals, who need to feel that their selves and identities are secure, become attached to some routine patterns of behaviour to provide their physical and ontological security. According to that argument, the continuation of the routines that individuals experience in social life, in other words the continuation of the social structure that is being shaped by repeated patterns of behaviour, is the main element that shapes their security perception. With the motivation of being secure, the individuals escape from cognitive and emotional uncertainties/instabilities, perceived as threats, and become attached to these routines that provide them with stability. The foreseeable patterns of behaviour in the relationship of the "others" with the "self", give a feeling of ontological security; thus these "knowable contacts" are preserved by being attached to them.

Relying on Giddens' formulation, ontological security studies in the International Relations discipline pass from the individual level to the state level and by antropomorphizating the state, they question the inter-state routines, state identities and behaviours, which cannot be understood by the studies on physical security; and make ontological security-based explanations in this sense. Ontological security researches, such as Rumelili and Karadağ's, criticize imprisonment of state security into physical security and defining of security solely through the concepts like danger, threat and survival. Instead, they point out much more abstract concepts such as identity and value. Basic determinants of identity, which are specially chosen to provide ontological security, are religion and nationalism. At this point, what lies at the centre of many chronic international relations problems alongside a quest for ontological security, appears to be a state of ontological insecurity and anxiety, too, driving from clashes of identity. This provides us with a functional tool for the solution of inter-society/inter-state conflicts. For that reason, it is possible to analyze many problems that drag the attention nowadays, such as identity crises, international terrorism, ethnic clashes, territorial demands, the refugee problem, economic depression and the rise of far-right, through an ontological security perspective. Mitzen, for example, 
78

Güvenlik Stratejileri

Cilt: 17

Sayı: 37

benefited from the concept of ontological (in)security, while interpreting irrational state behaviour or long-term conflicts, such as the IsraelPalestine problem and the US' intervention in Iraq. According to Mitzen, with some unreasonable and quite risky behaviour, states reconstruct their identities despite the possibility of being physically harmed. Ironically, by being nourished from the clash with the Other, these states carry their entity to the future; thus, feeling ontologically secure.

With its conceptual and practical dimensions, this study aims to descriptively examine the ontological security approach, which is directly linked to the routines, social interactions and stability in the lives of both the societies and the states as well as the individuals. With this target, through a wide literature review, the article presents the related discussions and case studies, which have been made in the international level. It also gives place to the related researches in Turkey, though their numbers are quite limited. The idea here is to introduce the ontological security approach to the wider masses and contribute to the analytical enrichment of future studies on security and foreign policy analysis. With its interdisciplinary structure and strong theoretical background, ranging from constructivism and post-structuralism to feminism and postcolonialism, the ontological security approach exceedingly holds such potential.

\section{Kaynakça}

Kitaplar

BİLGIN, Pınar, "Identity/Security", J. Peter Burgess, (ed.), The Routledge Handbook of New Security Studies, Routledge, New York, 2010, 81-89.

BILLGIN, P. ve İnce, Başak, "Ontological (In)security of 'Included' Citizens: The Case of Early Republican Turkey (1923-1946)", Bahar Rumelili, (ed.), Conflict Resolution and Ontological Security, Routledge, New York, 2015, 117-133.

BOOTH, Ken, Dünya Güvenliği Kuramı, Küre Yayınları, İstanbul, 2012.

BUZAN, Barry, People, States and Fear: An Agenda for International Security Studies in the Post-Cold War Era, (2nd Edition), ECPR Press, Colchester, 2007.

BUZAN, B., Wæver, Ole ve Wilde, Jaap De, Security: A New Framework for Analysis, Lynne Reinner Publishers, Colorado, 1998. 
Uluslararası İlişkiler Disiplininde Ontolojik Güvenlik Teorisi:

Kavram ve Literatür Odaklı Bir İnceleme

CHACE, James ve Carr, Caleb, America Invulnerable: The Quest for Absolute Security from 1812 to Starwars, Summit Books, New York, 1988.

CHAKRABARTY, Dipesh, Provincializing Europe: Postcolonial Thought and Historical Difference, Princeton University Press, Princeton, 2000, 97-113.

CRAIB, Ian, Anthony Giddens, Routledge, New York, 2011.

ÇELIK, Ayşe Betül, "The Kurdish Issue and Levels of Ontological Security", Bahar Rumelili, (ed.), Conflict Resolution and Ontological Security, Routledge, New York, 2015, 52-70.

DARWICH, May, Threats and Alliances in the Middle East: Saudi and Syrian Policies in a Turbulent Region, Cambridge University Press, United Kingdom, 2019.

DÜZGÜN, Aslı Nur, "Turkish Foreign Policy towards Israel (2008-2019): Routines, Identity and Ontological Security", Zülfükar Aytaç Kişman (ed.), Turkey in International Arena: Political and Economic Relations, Editura Universităţii "Aurel Vlaicu", Arad, 2019, 13-46.

EJDUS, Filip, Crisis and Ontological Insecurity: Serbia's Anxiety over Kosovo's Secession, Palgrave Macmillan, Switzerland, 2020.

ERIKSON, Erik H., Identity and the Life Cycle, W.W. Norton\&Company, New York, 1959.

ERIKSON, E. H., Insight and Responsibility: Lectures on the Ethical Implications of Psychoanalytic Insight, W.W. Norton \& Company, 1964.

ERIKSON, E. H., Childhood and Society, Paladin Books, London, 1977.

FOUCAULT, Michel, Discipline and Punish: The Birth of the Prison, Vintage Books, New York, 1977.

FOUCAULT, M., On the Genealogy of Ethics: An Overview of Work in Progress, Pantheon, New York, 1984.

GARFINKEL, Harold, Studies in Ethnomethodology, Prentice Hall, New Jersey, 1967.

GIDDENS, Anthony, Central Problems in Social Theory: Action, Structure and Contradiction in Social Analysis, Palgrave Macmillan, England, 1979.

GIDDENS, A., The Constitution of Society: Outline of the Theory of Structuration, University of California Press, Berkeley, 1984.

GIDDENS, A., The Consequences of Modernity, Polity Press, United Kingdom, 1990.

GIDDENS, A., Modernity and Self-Identity: Self and Society in the Late Modern Age, Polity Press, Cambridge, 2006.

GOFFMAN, Erving, Stigma: Notes on the Management of Spoiled Identity, PrenticeHall, New Jersey, 1963.

GOFFMAN, E., Interaction Ritual: Essays on Face-to-Face Behaviour, Anchor Books, 1967.

GOFFMAN, E., Encounters: Two Studies in the Sociology of Interaction, Penguin University Books, 1972.

HEIDEGGER, Martin, Being \& Time, (Çev. J. Macquarrie \& E. Robinson), Blackwell Publishers, Oxford, 1962.

HUSSERL, Edmund, Phenomenology and the Crisis of Philosophy, Harper \& Row, New York, 1965.

KIERKEGAARD, Soren, Kaygı Kavramı, (çev. Türker Armaner), Türkiye İş Bankası Kültür Yay., İstanbul, 2013. 
Helin SARI ERTEM - Aslı Nur DÜZGÜN

80

Güvenlik

Stratejileri

Cilt: 17

Sayı: 37

KINNVALL, Catarina, "Globalization, Identity, and the Search for Chosen Traumas", Kenneth Hoover, (ed.), The Future of Identity: Centennial Reflections on the Legacy of Erik Erikson, Lexington Books, Oxford, 2004, 111-136.

KINNVALL, C., Globalization and Religious Nationalism in India: The Search for Ontological Security, Routledge, New York, 2006.

KINNVALL, C., "Fear, Insecurity and the (Re)Emergence of the Far Right in Europe", Paul Nesbitt-Larking, C. Kinnvall, Tereza Capelos ve Henk Dekker, (eds.), The Palgrave Handbook of Global Political Psychology, Palgrave Macmillan, England, 2014, 316-335.

KRISTEVA, Julia, Powers of Horror: An Essay of Objection, University Presses of California, Columbia and Princeton, 1982.

LAING, Ronald D., The Divided Self: An Existential Study in Sanity and Madness, Penguin Classics, 1990, (ilk basim y1l1 1959).

MCSWEENEY, Bill, Security, Identity and Interests: A Sociology of International Relations, Cambridge University Press, Cambridge, 1999.

RUMELILI, Bahar, Conflict Resolution and Ontological Security, Routledge, New York, 2015.

RUMELILI, B., "Ontological (In)security and Peace Anxieties: A Framework for Conflict Resolution", B. Rumelili (ed.), Conflict Resolution and Ontological Security, Routledge, New York, 2015, 10-29.

RICHARDS, Barry, "Extreme Nationalism and the Hatred of the Liberal State", Nicolas Demertzis (ed.), Emotions in Politics: The Affect Dimension in Political Tension, Palgrave Macmillan, England, 124-142.

SCHUTZ, Alfred, The Phenomenology of the Social World, Northwestern University Press, London, 1967.

STEELE, Brent J., Ontological Security in International Relations: Self-Identity and the IR State, Routledge, New York, 2008.

STEELE, B. J. ve Innes, Alexandria J. "Memory, Trauma and Ontological Security", Erica Resende ve Dovile Budryte, (ed.), Memory and Trauma in International Relations: Theories, Cases and Debates, Routledge, New York, 2014, 15-29.

ŞİRAZİ, Hafız, Şark İslam Klasikleri Hafiz Divanı, (çev. Abdülbaki Gölpınarlı), MEB Yayınları, İstanbul, 1992.

THUCYDIDES, The War of the Peloponnesians and the Athenians, (der. ve çev. Jeremy Mynott), Cambridge University Press, Cambridge, 2013.

\section{Makaleler}

ADLER NIESSEN, Rebecca, "Stigma Management in International Relations: Transgressive Identities, Norms, and Order in International Society", International Organization, 2014, Cilt: 68, No: 1, 143-176.

BİLGIN, Pınar ve İnce, Başak, "Security and Citizenship in the Global South: In/securing Citizens in Early Republican Turkey (1923-1946)", International Relations, 2015, Cilt: 29, No: 4, 500-520.

GUSTAFSSON, Karl ve Krickel-Choi, Nina C, "Returning to the roots of ontological security: insights from the existentialist anxiety literature", European Journal of International Relations, 2020. 
Uluslararası İlişkiler Disiplininde Ontolojik Güvenlik Teorisi:

Kavram ve Literatür Odaklı Bir İnceleme

HUYSMANS, Jef, "Security! What Do You Mean?: From Concept to Thick Signifier", European Journal of International Relations, 1998, Cilt: 4, No: 2, 226-255. ILGIT, Aslı ve Prakash, Deepa, "More than a Feeling: Emotional Responses to International Critism in Erdogan's Turkey", Review of International Studies, 2017, Cilt 43, 130-151.

KINNVALL, Catarina, "Nationalism, Religion and the Search for Chosen Traumas", Ethnicities, 2002, Cilt: 2, No: 1, 79-106.

KINNVALL, C., "Globalization and Religious Nationalism: Self, Identity, and the Search for Ontological Security", Political Psychology, 2004, Cilt: 25, No: 5, 741-767. KINNVALL, C. ve Lindén, Jitka, "Dialogical Selves between Security and Insecurity Migration, Multiculturalism, and the Challenge of the Global", Theory \& Psychology, 2010, Cilt: 20, No: 5, 595-619.

KINNVALL, C., "Feeling Ontologically (In)secure: States, Traumas and the Governing of Gendered Space", Cooperation and Conflict, 2016, Cilt: 52, No: 1, 90-108.

KINNVALL, C. ve Svensson, Ted, "Ontological Security and the Limits to a Common World: Subaltern Pasts and the Inner-Worldliness of the Tablighi Jama'at", Postcolonial Studies, 2017, Cilt: 20, No: 3, 333-352.

KINNVALL, C. ve Cash, John "Postcolonial Bordering and Ontological Insecurities", Postcolonial Studies, 2017, Cilt: 20, No: 3, 267-274.

KINNVALL, C. ve Mitzen, Jennifer, "An Introduction to the Special Issue: Ontological Securities in World Politics", Cooperation and Conflict, 2017, Cilt: 52, No: 1, 3-11.

KINNVALL, C., "Racism and the Role of Imaginary Others in Europe", Nature Human Behaviour, Cilt: 1, No: 0122, 2017, s.1-4.

KINNVALL, C., Manners, Ian ve Mitzen, Jennifer, "Introduction to 2018 Special Issue of European Security: Ontological (In)Security in the European Union", European Security, 2018, Cilt: 27, No: 3, 249-265.

KINNVALL, C. ve Mitzen, Jennifer, "Ontological Security and Conflict: The Dynamics of Crisis and the Constitution of Community", Journal of International Relations and Development, 2018, Cilt: 21, No: 4, 825-835.

KINNVALL, C., "Ontological Insecurities and Postcolonial Imaginaries: The Emotional Appeal of Populism", Humanity \& Society, Cilt: 42, No: 4, 2018, s. 523-543.

KINNVALL, C., "Populism, Ontological Insecurity and Hindutva: Modi and the Masculinization of Indian Politics, Cambridge Review of International Affairs, 2019, 1-20.

KINNVALL C. \& Mitzen J., "Anxiety, fear, and ontological security in world politics: Thinking with and beyond Giddens", 2020, International Theory, 12(2), 240-256.

KULA, Sedat ve Çakar, Bekir, "Maslow İhtiyaçlar Hiyerarşisi Bağlamında Toplumda Bireylerin Güvenlik Algısı ve Yaşam Doyumu Arasındaki İlişki", Bartın Üniversitesi IIBF Dergisi, 2015, Cilt: 6, No: 12, 191-210.

MANNERS, Ian, "European [security] Union from existential threat to ontological security", Kopenhag Barış Araştırmaları Enstitüsü (COPRI), 2002, Cilt: 42, 1-43.

MASLOW, Abraham H., "The Dynamics of Psychological Security-Insecurity", Character \& Personality; A Quarterly for Psychodiagnostic \& Allied Studies, 1942, 10, 331-344.

MASLOW, Abraham H., "A Theory of Human Motivation", Psychological Review, 1943, Cilt: 50, No: 4, 370-396. 
82

Güvenlik Stratejileri

Cilt: 17

Sayı: 37

MCSWEENEY, Bill, "Identity and Security: Buzan and the Copenhagen School", Review of International Studies, Say1: 22, No: 1, 1996, 81-93.

MCSWEENEY, B., "Durkheim and the Copenhagen School: A Response to Buzan and Wæver", Review of International Studies, Sayı: 24, No: 1, 1998, 137-140.

MITZEN, Jennifer, "Ontological Security in World Politics, and Implications for the Study of European Security", CIDEL Workshop, 2004, 1-52.

MITZEN, J., "Ontological Security in World Politics: State Identity and the Security Dilemma", European Journal of International Relations, 2006, Cilt:12, No: 3, 341-370.

MITZEN, J., "Anchoring Europe's Civilizing Identity: Habits, Capabilities and Ontological Security", Journal of European Public Policy, 2006, Cilt: 13, No:2, 270-285.

MITZEN, J., "Security Communities and the Unthinkabilities of War", The Annual Review of Political Science, 2016, Cilt: 19, 229-248.

MITZEN, J. ve Larson, Kyle, "Ontological Security and Foreign Policy", Oxford Research Encyclopedia of Politics, 2017, 1-26.

MITZEN, J., "Anxious Community: EU as (In)security Community", European Security, 2018, Cilt: 27, No: 3, 393-413.

MITZEN, J., "Feeling at Home in Europe: Migration, Ontological Security, and the Political Psychology of EU Bordering", Political Psychology, 2018, Cilt: 39, No: 6, 1373-1386.

MORGAN, Patrick, "Safeguarding Security Studies", Arms Control, 1992, Cilt: 13, No: 3, 464-479.

NIESSEN, Rebecca Adler, "Stigma Management in International Relations: Transgressive Identities, Norms, and Order in International Society", International Organization, 2014, Cilt: 68, No: 1, 143-176.

ÖNIŞ, Ziya, "The Age of Anxiety: The Crisis of Liberal Democracy in a PostHegemonic Global Order", The International Spectator, 2017, Cilt: 52, No:3, 18-35.

ÖKTEM, Ülker, "Fenomenoloji ve Edmund Husserl'de Apaçıklı (Evidenz) Problemi", Ankara Üniversitesi Dil ve Tarih-Coğrafya Fakültesi Dergisi, 2005, Cilt:45, Say1: 1, $27-55$.

RUMELILİ, Bahar, "Identity and Desecuritization: Possibilities and Limits", NUPI's Research Seminar Series, 2011, Oslo, February, 1-36.

RUMELİLI, B., "Uluslararası İlişkilerde Kimlik ve Ontolojik Güvenlik", Bilim ve Sanat Vakfi, Bülten, Cilt: 83, İstanbul, 9 Ekim 2013, 8-10.

RUMELILI, B., "Identity and Desecuritization: The Pitfalls of Conflating Ontological and Physical Security", Journal of International Relations and Development, 2013, 1-23.

RUMELILİ, B. ve Karadağ, Sibel, "Göç ve Güvenlik: Eleştirel Yaklaşımlar", Toplum ve Bilim, 2017, Cilt: 140, 69-92.

RUMELILI, B., "Breaking with Europe's Pasts: Memory, Reconciliation, and Ontological (In)security”, European Security, 2018, Cilt: 27, No: 3, 280-295.

RUMELILİ, B. ve Adısönmez, Umut Can, "Uluslararası İlișkilerde Kimlik Güvenlik İlişkisine Dair Yeni bir Paradigma: Ontolojik Güvenlik Teorisi”, Uluslararası İlişsiler, 15 Nisan 2020, 1-17.

RUMELILI, B., "Integrating Anxiety into International Relations Theory: Hobbes, Existentialism, and Ontological Security", International Theory, Cilt: 12, No:2, 2020, 257-272. 
Uluslararası İlişkiler Disiplininde Ontolojik Güvenlik Teorisi:

Kavram ve Literatür Odaklı Bir İnceleme

SARI ERTEM, H., "Kimlik ve Güvenlik İlişkisine Konstrüktivist Bir Yaklaşım: 'Kimliğin Güvenliği' ve 'Güvenliğin Kimliği”, Güvenlik Stratejileri Dergisi, 2012, Cilt:16, Cilt: 16, 177-234.

SAYAR, Kemal, "Varoluş̧̧u Psikoloji Açısından Anksiyete: Kierkegaard ve Anksiyete", https://kemalsayar.com/insana-dair/varoluscu-psikoloji-acisindan-anksiyete,(Erişim Tarihi: 11.10.2020).

STEELE, Brent J., "Ontological Security and the Power of Self-Identity: British Neutrality and the American Civil War", Review of International Studies, 2005, Cilt: 31, No: 3, 519-540.

STEELE, B. J., "Making Words Matter: The Asian Tsunami, Darfur, and "Reflexive Discourse" in International Politics", International Studies Quarterly, 2007, Cilt: 51, No: 4, 901-925.

STEELE, B. J., " 'Ideals That Were Really Never in Our Possession': Torture, Honor and US Identity", International Relations, 2008, Cilt: 22, No: 2, 243-261.

STEELE, B. J. ve Delehanty, Will K. "Engaging the Narrative in Ontological (In)security Theory: Insights from Feminist IR", Cambridge Review of International Affairs, 2009, Cilt: 22, No: 3, 523-540.

STEELE, B. J., "Organizational Processes and Ontological (In)security: Torture, the CIA and the United States", Cooperation and Conflict, 2017, Cilt: 52, No: 1, 69-89.

STEELE, B. J. ve Subotic, Jelena, "Moral Injury in International Relations", Journal of Global Security Studies, 2018, Cilt: 3, No: 4, 387-401.

STEELE, B. J. ve Homolar, Alexandra, "Ontological Insecurities and the Politics of Contemporary Populism", Cambridge Review of International Affairs, 2019, 1-8.

STEELE, B. J., "Welcome Home! Routines, Ontological Insecurity and the Politics of US Military Reunion Videos", Cambridge Review of International Affairs, 2019, 1-22.

STEELE, B. J. ve Donnelly, Faye, "Critical Security History: (De)securitisation, Ontological Security, and Insecure Memories", European Journal of International Security, 2019, No: 4, 209-226.

VOLKAN, Vamık D., Bloodlines: From Ethnic Pride to Ethnic Terrorism, Basic Books, New York, 1998.

WENDT, Alexander, "Collective Identity Formation and the International State", American Political Science Review, Cilt: 88, No: 2, 384-396.

WOLFERS, Arnold, "National Security as an Ambiguous Symbol", Political Science Quarterly, 1952, Vol. 67, No.4, 481-502.

YILDIRIM, Engin, “Anthony Giddens'ın Yapılanma Teorisi”, Bilgi Sosyal Bilimler Dergisi, 1999, Cilt: 1, 25-44.

Tezler

SARI ERTEM, Helin, Geleneksel Amerikan Kimlik ve Güvenlik Algısının 11 Eylül Sonrası ABD Dış Politikasına Etkileri, Doktora Tezi, Marmara Üniversitesi Sosyal Bilimler Enstitüsü, İstanbul, 2010. 